\title{
Comparison of the Volume of Crevicular Fluid from Restored and Nonrestored Teeth
}

Lee Jameson

Loyola University Chicago

Follow this and additional works at: https://ecommons.luc.edu/luc_theses

Part of the Oral Biology and Oral Pathology Commons

\section{Recommended Citation}

Jameson, Lee, "Comparison of the Volume of Crevicular Fluid from Restored and Nonrestored Teeth" (1976). Master's Theses. 2815.

https://ecommons.luc.edu/luc_theses/2815

This Thesis is brought to you for free and open access by the Theses and Dissertations at Loyola eCommons. It has been accepted for inclusion in Master's Theses by an authorized administrator of Loyola eCommons. For more information, please contact ecommons@luc.edu. (c) $($ ) $(9)$

This work is licensed under a Creative Commons Attribution-Noncommercial-No Derivative Works 3.0 License. Copyright (C) 1976 Lee Jameson 
COMPARISON OF THE VOLUME OF CREVICULAR FLUID

FROM RESTORED AND NONRESTORED TEETH

\author{
by \\ Lee Merle Jameson \\ D.D.S., Loyola University, 1974
}

A Thesis Submitted to the Faculty of the Graduate School of Loyola University of Chicago in Partial Fulfillment of the Requirements for the Degree of Master of Science

$$
\begin{aligned}
& \text { June } \\
& 1976
\end{aligned}
$$




\section{ACKNOWLEDGEIENTS}

The author wishes to acknowledge the members of the Advisory Committee: Dr. William Malone, Dr. Robert Pollack Jr., and Dr. Patrick Toto for their time and cooperation in finalizing this thesis. A special note of appreciation to Dr. Malone for his dedication, tireless support, and guidance during this investigation.

A sincere expression of gratitude is extended to Harco Electronics for supplying the gingival crevicular fluid meter used in this study.

Lastly, special recognition to my wife, Loretta, whose loyalty and angelic understanding helped share the burden and to my parents whose unselfish devotion and encouragement will always be remembered. 
VITA

The author, Lee Merle Jameson, is the son of Donovan Edward Jameson and Josephine (Wolf) Jameson. He was born May 28, 1946, in Peoria, Illinois.

His elementary education was obtained in the public schools of Peoria, Illinois, and secondary education at Richwoods Community High School, Peoria, Illinois, where he graduated in 1964.

In September of 1964, he entered Bradley University, Peoria, Illinois, and recelved the degree of Bachelor of Science in June of 1968, majoring in biology.

In September of 1968, he was employed by East Peoria Grade School District as a science teacher at Central Junior High School, East Peoria, Illinois until June of 1970.

In September of 1970, he entered Loyola University School of Dentistry, Chicago, Illinois, and in June of 1974 he received the degree of Doctor of Dental Surgery. While attending Loyola Dental School he was vice-president (1973) and president (1974) of XI Psi Phi Professional Dental Fraternity. His cumulative grade point placed him on the Dean's list from 1971 to 1974. In 1974, he received the American Academy of Crown and Bridge Award and was inducted into Blue Key National Honor Fraternity.

In 1974, he became an alumi member of Xi Psi Phi 
Professional Dental Fraternity and a graduate studsnt member of the American Dental Association and the Chicago Dental Society.

In 1974, he entered the postgraduate clinical speciality training program in Fixed Prosthodontics and the graduate program in Oral Blology at Loyola University Dental School, Chicago, Illinois. 
TABLE OF CONTENTS

Page

ACKNOWLEDGEMENTS $\ldots \ldots \ldots \ldots \ldots \ldots \ldots \ldots \ldots \ldots \ldots \ldots$ il

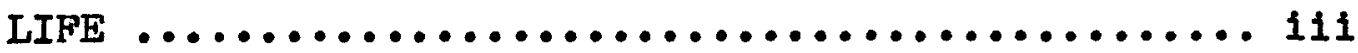

IIST OF TABLES $\ldots \ldots \ldots \ldots \ldots \ldots \ldots \ldots \ldots \ldots \ldots \ldots \ldots \ldots$

LIST OP ILLUSTRATIONS $\ldots \ldots \ldots \ldots \ldots \ldots \ldots \ldots \ldots \ldots \ldots \ldots$ vi

CONTENTS OP APPENDIX .................... vii

Chapter

I. INTRODUCTION AND STATEMENT OF PURPOSE ..... 1

II. BEVIEW OF THE LITERATURE ............ 2

Historical Perspective ............ 2

Classical Literature ............ 3

Recent Literature .............. 18

Clinical Literature ............ 25

III. MATERIALS AND METHOD ............... 33

IV. EXPERTMENTAL RESULTS .............. 45

V. DISCUSSION ...................... 53

VI. SUMMARY AND CONCLUSIONS ............. 58 BIBLIOGRAPHY .......................... 60

APPENDIX ............................. 6 ? 


\section{LIST OF TABLES}

Table Page

1. Compiled Data ...................... 47

2. Analysis of Variance Table ............. 50

3. Mean Values of Gingival Index, Pocket Depth, and GCF Beadings ......... 51

4. Frequency Distribution of Restorations .... 52 
LIST OF ILLUSTRATIONS

Figure

Page

1. Orfice Method for Crevicular Fluid

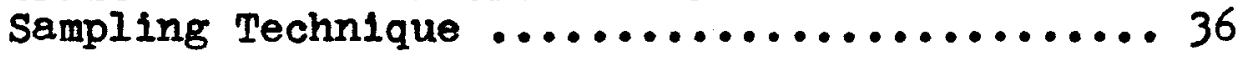

2. Gingival Crevicular Fluid Meter-Model

$\mathrm{HR}-600$............................ 37

3. Periotron ${ }^{\oplus}$ (Clinical GCP Meter) ........... 38

4. Measuring Sulcus Depth ................. 39

5. Sterile Filter Paper Strips ............ 40

6. Holding card for Filter Paper Strips ........ 41

7. Filter Paper Strip Prior to collection of Crevicular Fluid ....................... 42

8. Gingival Crevicular Fluid Collection Technique ..........................44 43

9. Placing Filter Paper Strip Between the Recording Sensors of GCF Meter ......... 44 


\section{CONTENTS OF APPENDIX}

Patient Consent Form 


\section{CHAPTER I}

\section{INTRODUCTION AND STATEMENT OF PURPOSE}

One of the main objectives of the clinical dentist is the restoration of missing natural tooth contours. The procedures and inherent qualities of the materials involved in this undertaking make preservation of the supporting gingival tissue an arduous task. Even with minimal preinsertion disruption of the soft tissue, the re-establishment of marginal contours conducive to periodontal health is a continual problem. The detrimental effects to the periodontium, specifically the marginal gingiva, have been observed clinically. However, until recently no quantitative measurement could be made to assess the degree of change. A gingival crevicular fluid meter (Harco) has been developed which electronically measures minute fluid volume by the reduction in capacitance between two sensors when in contact with a standardized filter strip containing the fluid to be measured. With this instrument, any inflammatory change occurring within the marginal gingiva, can be detected before clinical signs become evident. It is known that crevicular fluid volume increases with an increase in inflammation; therefore, the purpose of this investigation is to determine the inflammatory changes in the marginal gingiva after insertion of full coverage restorations utilizing a crevicular fluid meter. 
In G.V. Black's (1887) histologic evaluation of the periodontal membrane, he referred to a gingival fluid in his statement, "Indeed, close clinical examination makes it apparent that there is a slight secretion at this point that is not quite satisfactorily explained even yet by microscopic study of the part." Black (1899) refuted Serres: (1817) description of gingival glands and attempted to show histologic evidence of a deeper plexus of gingival glandular tissue clustered among the principal fibers of the periodontal membrane and encircling the root. By 1920 Black postulated the subginglval space was continually bathed by a fluid which contributed to subgingival calculus formation.

McCall (1924) postulated teeth in traumatic occlusion altered the periodontal tissue resulting in acidity in the exudate of the gingival crevice.

Stillman and McCall (1927) Iisted as one of the functions of the marginal gingiva "...being the cleansing of the enamel surface over which it lies by the serous secretion from its crevicular surface."

Böedecker (1931) found no histological evidence of a 
plexus of gingival glands as described by Black (1899). However, Böedecker (1933) agreed with McCall's theory and examined human gingival fluid using litmus paper to determine "the relation of an acid exudate of the gingival crevice to erosion."

Miller (1938) defined the term 'crevicular exudate' as a "discharge from the gingival crevice" and listed changes in the crevicular exudate as a clinical sign of incipient periodontal disease. He stated, "Frequently, even with clinical signs of periodontal disease lacking, microscopic examination of the crevicular fluid reveals the presence of an unusual number of pus cells."

Much attention was drawn to the gingival sulcular area as evidenced by the extensive histological survey of the gingival crevice and the epithelial attachment in Kronfeld's text (1933).

B. Classical Literature

Waerhaug (1952) demonstrated the dynamic nature of the gingival sulcus by placing India ink in the healthy gingival sulcus of young dogs. One hour after placement an emigration of leucocytes through the sulcular epithelium was noted in addition to an increased transudation of fluid.' Most of the India ink particles were removed by this fluid after two hours. He concluded saliva could not 
penetrate below the gingival margin and "In healthy pockets where a normal epithelial cuff is closely fitted around the tooth to the gingival margin, the secretion is rather minute."

Waerhaug and Steen (1952) introduced pure cultures of pathogenic bacteria into bacteria free gingival pockets of dogs and the histologic tissue reaction noted over a fortyeight hour time period. Their conclusions were: "From all pockets there is a constant flow of cellular elements and tissue fluid," (2) the healthy, calculus free gingival crevice is sterile, (3) bacteria within the sulcus cause necrosis of the epithelium and inflammation of the connective tissue with a subsequent exudate formation.

Brill and Björn (1959) studied the permeability of human crevicular epithelium to fluorescein molecules (orally administered) to see if this differentiated crevicular epithelium from other oral epithelium and nasal epithelium. Their results showed the epithelial lining of the gingival crevice and the nasal mucosa were permeable to fluorescein molecules. They noted a correlation between the degree of inflammation and the quantity of fluorescein recovered on filter strips placed in the gingival sulcus. More fluorescein was recovered from patients with extensive restorations compared to clinically healthy nonrestored marginal gingiva. 
Brill and Krasse (1959) working with dogs demonstrated that short term mechanical stimulation (externally and within the sulcus) of clinically healthy marginal gingiva resulted in an increased flow of tissue fluid from the gingival sulcus. The original flow rate (prior to stimulation) returned within ten minutes. The effects of various types of mechanical stimulation were evaluated from the quantity of fluorescein sodium recovered from the sulcus on filter paper strips after intravenous injection of the material. The investigators offered two explanations to account for the increased fluid flow: (1) a vascular bed mechanically stimulated results in arteriole dilatation with an increased pressure and an increased permeability of the vessels allowing plasma to escape which, in turn, increases the quantity of interstitial fluid, (2) the ground substance of the connective tissue matrix may be described as a sol $\rightleftarrows$ gel system which exists as a gel in the resting state and a sol when tissue is mechanically stimulated.

Brill (1959a) injected dogs with Evans' Blue (vital dye T-1824 which binds to plasma albumin in small concentrations and $\alpha-g l o b u l i n$ in larger concentrations) to assess fluid flow in the sulcular pocket as influenced by histamine, mechanical stimulation, and inflammatory state. He reasoned the dye being bound to plasma proteins could be used to monitor changes in the permeability of the gingival vessels 
and measure this change by the amount of dye recovered from filter paper strips placed in the ginglval sulcus. Brill concluded protein-bound Evans' blue from plasma passes through capillary walls in minute amounts and appears in gingival crevices as a result of: (1) mechanical stimulation, (2) intravenous injection of histamine, and (3) inflammation.

Brill (1959b) using paraffin and human subjects found vigorous chewing increased the flow of tissue fluid into the gingival crevice which he reasoned would have a bearing on gingival health. It was also noted sulcular fluid collected from both stimulated and unstimulated sulci contained amino acids (ninhydrin, triketohydrindene hydrate, staining technique which is specific for $\alpha$-amino groups). Brill concluded, "When gingival structures are stimulated by chewing, the antimicrobial effect may be increased, because mechanical stimulation of the gingival vascular bed stimulates escape of fluid from the vessels and plasma contains several antimicrobial substances."

Brill (1959c) utilized charcoal particles of known size $(2 \mu$ to $10 \mu)$ to study the flushing action of gingival fluid on non-vital particles and living bacteria. He concluded from the results, "that the flow of tissue fluid from subepithelial structures of marginal gingiva is able to remove particulate matter, including bacteria, from gingival pockets" (the term 'pocket' is defined by Brill to designate the space limited on one side by epithelium and on the other 
by tooth structure often ending at the cemento-enamel junction irrespective of the content of a pocket).

Brill and Brönnestam (1960) subjected human sulcular fluid to immunoelectrophoretic analysis and found seven different serum protein components present including $\alpha_{2}$ macroglobulin, $\beta$ and $\gamma g$ lobulin. From this information they concluded the fluid originates from tissue fluid and is extracellularly formed by filtration through capillaries.

Gavin and Collins (1961a) investigated the bacteriological status of the clinically healthy human gingival sulcus and refuted Waerhaug and Steen's (1952) previous conclusion concerning the sterility of the healthy gingival crevice. They concluded, "by the described method the clinically healthy gingival crevice appears to contain micro-organisms in the majority of cases." In a subsequent study (1961b), the same authors found human gingival fluid taken from clinically healthy ginglval crevices does not exhibit any bacteriostatic or bactericidal effect on various strains of oral bacteria (including Neisseria, Diphtheroids, Streptococci, and Staphylococci).

Löe (1961) studied the turn over rate of epithelial cells and the presence of leukocytes in crevicular fluid of dogs by sealing clinically normal ginglval crevices with an alcoholic solution of colophony (rosin) and covering the teeth with acrylic crowns filled with surgical cement and locked in place by amalgam. Histological examination of the 
specimens resulted in the following conclusions:

"mitotic figures along the entire length of the epithelial lining of the pocket and the desquamation of the surface cells support the view that the epithelial cuff is constantly renewed," (2) accumulation of neutrophilic leukocytes within the gingival sulcus indicates "that they migrate through the epithelial lining under physiological conditions," and (3) "there is a continuous transudation of tissue fluid into the clinically normal gingival pockets."

Gustafsson and Nilssen (1961) assessed human gingival fluid from clinically healthy gingiva for the presence of fibrinogen and fibrinolytic factors. Fibrinolysis was observed, indicating the presence of plasmin and activator in the crevicular fluid. They reasoned, "the fibrinolytic factors in the crevicular fluid might be of significance in counteracting the deposition of fibrin and other proteins at the junction between the gingival epithelium and the tooth."

Harvey (1962) determined that extraneous material (silver alloy with a particle size ranging from $0.25 \mathrm{~mm}$ to $1.0 \mathrm{~mm}$ in length and $0.1 \mathrm{~mm}$ to $0.25 \mathrm{~mm}$ in width) placed in the clinically healthy gingival crevices of dogs and humans will be eliminated by a physiological flow of tissue fluid from the crevice. It was suggested, "that the normal gingival crevice maintains its hygienic state by constant 
flushing with tissue fluid which is increased as a result 9 of an acute inflammatory response to irritation."

Krasse and Egelberg (1962) subjected human crevicular fluid to flame photometry to determine the relative proportions of sodium, potassium, and calcium. Their observations indicated a proportional increase of potassium from clinically healthy gingiva and reasoned that it was intra-cellular potassium added to the extra-cellular fluid as it left the tissue into the gingival sulcus. Thus, the conclusion was "that gingival pocket fluid cannot be regarded as a simple filtration product but rather as an inflammatory exudate."

Egelberg (1963a) compared the cellular content of gingival sulcus fluid from clinically healthy gingiva to fluid from chronically inflamed gingiva and observed no difference in quality of cells (both contained epithelial cells, polymorphonuclear leukocytes, lymphocytes, and bacteria). However, there was an increase of inflammatory cells compared to epithelial cells from the inflamed gingival samples. He reiterated his previous conclusion "fluid in healthy pockets may be regarded as an inflammatory exudate."

Egelberg (1963b) showed a histamine solution

$(10 \mathrm{mg} / \mathrm{ml}$ histamine) topically applied to the marginal and attached gingiva of both human subjects and dogs could 
penetrate the gingival crevicular epithelium but not the epithelium of the attached gingiva. This was based on the observation that the amount of gingival fluid (determined by the ninhydrin staining technique) increased compared to the amount of fluid collected from the sulcus before the application of the histamine. These findings were contrary to the previous suggestions of waerhaug (1955) and Brill (1959c) that the gingival fluid sealed the crevicular areas from penetration by various substances. Mann (1963) collected gingival fluid from human subjects using filter paper strips after they were given fluorescein sodium orally ( $325 \mathrm{mg})$. His results indicated: (1) as the gingival score (qualitative index by Parfitt) increased the crevicular fluid flow increased, and (2) high gingival scores were associated with high values of flow. He reasoned since there was minimal flow from healthy marginal gingiva and an increased flow from inflamed tissue the flow of gingival crevicular fluid is more dependent on inflammation than pocket depth. Applying analysis of correlation between the variables of pocket depth and inflammation and the presence of crevicular fluid, he concluded, "these variables indicated that inflammation was the main factor contributing to the rate of fluid flow."

Egelberg (1964) investigated crevicular fluid (humans and dogs for subjects) to determine if there was a correlation between clinical and histological criteria for 
gingival inflammation and the amount of gingival exudate recovered by filter paper strips. He found the gingival papilla area had a higher degree of inflammation and statistically there was a correlation between recorded amounts of exudate and the clinical scores for gingival inflammation. Although the sample size prevented a definitive conclusion, a correlation existed between the amount of gingival exudate collected on filter paper strips and the area of inflammatory cell infiltration as revealed by histologic sections measured planimetrically. Egelberg concluded, "that gingival exudate measurements can be considered a method which fulfills rather great demands in regard to objectivity and sensitivity and that with this method increased possibilities to study the effect of various factors on inflammation of the gingiva have probably been achieved."

Brandtzaeg and Mann (1964) examined the lysozymal activity of human gingival fluid, serum, and saliva (from seven patients with gingivitis and five with periodontitis) using Micrococcus lysodeikticus as a substrate and turbidimetric spectrocolorimetry techniques. They found crevicular lysozymal activity tended to increase with the severity of inflammation while serum and saliva did not exhibit this tendency. Since no correlation was observed between the three body fluids theyconcluded, "the enzyme in gingival fluid is assumed to be primarily of local origin, possibly 
derived from leukocytes."

Using agar electrophoresis, Carraro et al. (1.964) revealed the presence of albumin, alpha globulin, beta globulin and gamma globulin in human gingival fluid taken from clinically healthy gingiva. Prealbumin fraction present in human serum was not present in the gingival fluid. Weinstein and Mandel (1964) discussed the pertinent literature concerning the origin of crevicular fluid. In evaluating the various proposed mechanisms of gingival fluid production, they considered the most plausible explanation was to classify it as a specifically altered transudate from serum. Based on this explanation the epithelial cells lining the crevicular cells actively alter the passing fluid since: (1) these sulcular cells are continually being shed and the intracellular contents added to the transudate, (2) the cells may exhibit an active ionic transport mechanism, and (3) the crevicular cells may add a cytocellular fluid through micropores in the cell walls.

Löe and Holm-Pedersen (1965) measured crevicular fluid from 118 adults using an extracrevicular technique (Munktel No. 3 filter paper strip - $1.5 \mathrm{~mm} \times 10 \mathrm{~mm}$ - placed next to the tooth surface, the gingival margin, and the attached gingiva) and an intracrevicular technique (filter paper strip placed at the entrance of the gingival crevice). Using 
biomicroscopic techniques they noticed that inserting filter paper strips deep into the gingival sulcus resulted in capillary compression. Their conclusions were: (1) crevices of healthy human gingiva do not exhibit fluld flow (contrary to the findings of Brill-1962) and "mechanical stimulation of the periodontium does not produce fluid from such crevices" (contrary to the findings of Brill-1959b and Brill and Krasse-1959), (2) crevicular fluid flow begins prior to the appearance of clinical changes and persists for a while after clinical inflammatory changes have disappeared, and (3) "gingival fluid is an inflammatory exudate and that the absence or presence of fluid may represent the definite clinical criterion in the refined distinction between normal and inflamed gingiva."

Sueda et al. (1966) did a histochemical study of human gingival fluid, blood serum, and saliva. They found gingival fluid contained proteins, lipids, polysaccharides bound to proteins (muco-, glyco-, or 1ipo-proteins) and noted that the histochemical reactions were similar in gingival fluid and serum while they all were weak or absent in saliva. They stated their results seemed to confirm Cimasoni's (1966) hypothesis that a mucopolysaccharide substance identified by Toto and sicher (1964) found between the enamel and the crevicular epithelium of humans could represent a condensation of gingival fluid. 
Stallard (1967) injected plastic microspheres (15 \pm

$5 \mu \mathrm{m}$ ) into the external carotid artery of squirrel monkeys to to study the microcirculation of the periodontium. He found the average vessel diameter beneath the attached gingiva to be $16.8 \mu \mathrm{m}$. The configuration of the connective tissue-epithelial junction dictated the vascular arrangement since the vessels were parallel to the enamel surface in the area of the epithelial attachment. A large number of microspheres were trapped in areas of chronic inflammation "possibly associated with abnormal coiling of microvessels observed beneath the 'col' and sulcular epithelium." A correlation existed between the integrity of the microvasculature within the sulcular epithelium and the existence of gingival crevicular fluid. Stallard concluded, "initially, the inflammatory reaction, with its characteristic vascular alterations, is a physiologic defense mechanism; however, it appears that in the case of periodontal disease the inflammatory response eventually becomes pathologic." - Weinstein et al. (1967) using chemical, immunochemical, immunological and electron microscopic techniques derionstrated and characterized the existence of gingival fluid in the clinically normal human sulcus. The authors based their divergence from the findings of Löe et al. (1965) on the different criteria for 'clinically normal' and the uncontrolled differences in techniques. It is pointed out 
their technique using fluorescein labelling was 100 times more sensitive in detecting proteins than the ninhydrin staining technique used by Löe.

Kleinberg and Hall (1968) measured the $\mathrm{pH}$ and gingival crevice depth of fasting humans. Their results showed: (1) the crevice $\mathrm{pH}$ for each region of the mouth was higher than the $\mathrm{pH}$ of the supragingival plaque in the same region, (2) "the $\mathrm{pH}$ of crevices in mandibular regions was higher than the $\mathrm{pH}$ of crevices in corresponding maxillary regions, lingual crevices were more basic than labial-buccal crevices, and for combined maxillary and mandibular areas, anterior crevices were higher in $\mathrm{pH}$ than posterior crevices and interproximal crevices higher in $\mathrm{pH}$ than crevices in either lingual or labial-buccal regions," and (3) "up to a crevice depth of approximately $0.7 \mathrm{~mm}$, the $\mathrm{pH}$ increased whereas above this depth the $\mathrm{pH}$ decreased." The intraoral $\mathrm{pH}$ pattern for gingival crevices was similar to that for supragingival plaque suggesting "that saliva is also a determinant of the crevice $\mathrm{pH} . "$ The mechanism postulated for both $\mathrm{pH}$ patterns is that saliva in the presence of the plaque microflora and the crevice microflora favors the formation and accumulation of more base than acid resulting in a higher pH. They concluded "periodontal disease and caries are two interrelated pathological conditions that reflect the metabolism of the plaque and crevice microfloras 
each of which is associated with different regions of the pH scale."

Sandalli and wade (1969) examined the changes in crevicular fluid volume following gingivectomy and flap procedures. From their results they concluded: (1) initial scaling, polishing, and supervised oral hygiene reduced the gingival fluid flow, (2) there is a considerable reduction in gingival fluid flow four weeks post operatively (in agreement with Löe and Holm-Pedersen's findings-1965), and (3) "there is a relation between the depth of pocket and the amount of gingival fluid: measuring this amount may be of value in scoring the periodontal status."

Orban and Stallard (1969) measured crevicular fluid volume from a "group" of dental school patients to see if there was a correlation between fluid volume and clinical scoring techniques (Ramfjord's Periodontal Index and Greene and Vermillion's OHI-S) and biopsy specimens scored on a scale from zero to ten depending on the extent of inflammatory infiltrate. They suggested the intercellular cementing substance is modified by various factors (e.g. hyaluronidase, chewing, brushing, gingival massage, circadian rhythm and hormones) resulting in an increased permeability of the sulcular epithelium. Their data showed crevicular fluid scores were not directly related to either individual or representative biopsy scores and 
concluded, "a better indication of inflammatory status of the gingival tissues, as revealed by biopsies, is the evaluation or measurement of dental plaque."

oliver et al. (1969) examined fifty-three patients to study the relation between a gingival index (Löe and Silness-1967), gingival fluid measurements and histological inflammatory cell density. Their results showed the gingival index system strongly correlated with the amount of gingival exudation (ninhydrin staining technique) and in patients with "no clinical evidence of gingival inflammation there is not exudate in the vast majority of crevices." Turner et al. (1969) studied the microcirculation of the healthy periodontium in dogs by injecting a one per cent solution of Patent Blue $\mathrm{V}$ in one carotid artery and filtered Pelikan carbon black suspension (Gunter and Wagner) in the other. They found: (1) one per cent Patent Blue V "passes quickly through the epithelial attachment and the sulcular epithelium into the gingival sulcus," (2) "the Patent Blue perfusion offers some evidence that a dye labelled-transudate passed from the capillary loops of the peripheral vascular plexus of the gingiva and entered the intercellular matrix, since there is evidence of tissue staining," and (3) Pelikan carbon black suspension (particle size 200 to $500 \AA$ ) "does not pass through the intact capillary wall." They concluded, "Further investigations 
have indicated there may be a 'free' flow of fluid

through the gingiva and thence through an apparently highly pervious sulcular epithelium-assuming there is, investigation must determine how this network carries this transudate and the mediating influence upon the process."

\section{c. Recent Literature}

Zájiček and Kindlová (1972) measured the endogenous consumption of oxygen by human gingiva in varying inflammatory conditions using Šerák's polargraphic method. Their results showed a significant difference in the rate of decrease of oxygen consumption values with a greater percentage decrease per hour occurring in the slightly inflamed group and the smallest percentage decrease per hour occurring in tissue samples with the highest degree of inflammation.

Renggli and Regolati (1972) measured gingival fluid (ninhydrin technique) and collected intracrevicular leukocytes from the maxillary anterior teeth of five subjects with excellent oral hygiene. They found: (1) clinically healthy gingival crevices contained leukocytes, (2) the leukocyte count varied considerably among subjects, teeth, and days, and (3) no correlation existed between gingival fluid flow rate and the relative number of leukocytes. Egelberg and Attström (1973) compared the orfice and intracrevicular methods for measuring gingival fluid on both 
humans and beagle dogs. Their results indicated both methods were "comparable for evaluation of intra-individual changes of gingival inflammation" and "the orfice method showed statistically significant differences at a few more time point comparisons than the intracrevicular method." They concluded the orfice method had less variation between samples.

Alfano (1974) discussed a theoretical model of fluid transport to explain the origin of gingival fluid and the opposing experimental results which described it either as a physiological transudate or a pathological inflammatory exudate. His proposed theory was gingival crevicular fluid arises by two distinct mechanisms: (1) the generation of a standing osmotic gradient generated by macromolecular by-products of the bacteria present in the subgingival dental plaque, and (2) the initiation of the classical inflammatory response. Thus, "at various times or in different areas of the mouth, gingival fluid may progress from an initial osmotically-modulated to a secondary inflammatory exudate, with consequent alterations in its composition."

Borden et al. (1974) measured human crevicular fluid flow using a fluid meter (Harco Electronics ITD., Winnipeg, (anada) to compare extracrevicular and intracrevicular collection techniques and note any correlation between gingival fluid flow and the Gingival Index (Löe and Silness- 
1967). Their results showed: (1) "repeated intracrevicular measurements gave similar gingival fluid flow rates," (2) the three seconds intracrevicular measurement of crevicular fluid flow was more sensitive than the extracrevicular technique, (3) "repeated intracrevicular measurements did not significantly stimulate fluid flow," (4) the recommended technique for measuring crevicular fluid with GCF Meter involves initially emptying the crevicular pool with a paper strip followed by a thirty seconds interval and three seconds placement of a fresh filter paper strip for measurement, and (5) measuring gingival crevicular fluid flow is an objective method for monitoring gingival inflammation. They stated their"results indicated that the extracrevicular technique is unsatisfactory for slightly inflamed gingival crevices, since GCF may have difficulty flowing out of such crevices."

Shern et al. (1974) compared the ninhydrin staining method and the crevicular fluid flow meter (Harco) for quantifying human (sixty males) crevicular fluid flow. They found "precision, accuracy and reliability of measuring crevicular flow proved greater using a flow meter than using the ninhydrin dye method." Their conclusion was using the combination of crevicular fluid flow measurements (GCF Meter) and cytological smears "could provide valuable physiologic measurements for clinical trials."

Golub et al. (1974) studied the collagenolytic activity 
of human gingival crevicular fluid and found no detectable collagenolytic activity from gingiva with a mean pocket depth of $2.38 \pm 0.26 \mathrm{~mm}$ and a mean gingival crevicular fluid volume of $0.16 \pm 0.02 \mu \mathrm{I}$ (GCF Meter-Harco). However, positive activity was found in gingiva with a mean pocket depth of $2.61 \pm 0.26 \mathrm{~mm}$ and a mean volume of $0.26 \pm 0.05 \mu \mathrm{l}$. Thus, collagenolysis in human gingival crevicular fluid tended to be associated with gingiva exhibiting increased inflammation. Lie and Selvig (1975) formed an experimental dental cuticle on the surfaces of human enamel, dentin, cementum, and a control material composed of an epoxsy resin with exposed synthetic hydroxyapatite crystals when incubated in human serum for eighteen hours at thirty-seven degrees centigrade. Their observations suggested in vivo the dental cuticle is partly formed by "adsorption of material from serum and tissue fluid which may have seeped through the junctional epithellum as gingival exudate." They stated the observed variations in thickness of the dental cuticle support the hypothesis the cuticle is not an anatomical structure, but rerlects "the ubiquitous presence of inflammation of the gingiva and exudation through the junctional epithelium." Holm-Pedersen et al. (1975) induced experimental gingivitis in young and elderly subjects by having them abstain from oral hygiene procedures for a twenty-one day period of time. They found no difference between samples 
from elderly and young subjects in regards to the percentage distribution of various types of bacteria throughout the entire study. Gingival inflammation occurred more rapidly and severly in the elderly individuals and a slightly slower tissue recovery was observed in the elderly subjects

following re-initiation of oral hygiene procedures. Measuring crevicular fluid flow revealed a difference between young and elderly individuals more markedly than the Gingival Index (Löe and Silness-1967) indicating "a more sensitive diagnostic aid in the assessment of minor gingival changes." They stated the "observed differences in development of gingivitis suggest an altered host response to the plaque microorganisms with age."

Mäkinen and Hyyppä (1975) quantitated arginine aminopepidase activity in human gingival fluid (in varying clinical states), centrifuged whole saliva, plaque water extract, serum, and erythrocytes. Their results indicated: (1) an enzyme resembling aminopeptidase $B$ was found in all gingival fluid samples, (2) "the specific activity of the hydrolytic enzymes was correlated with the intensity of periodontal inflammation," (3) clinically healthy gingiva exhibited fluid that contained the same enzymes as fluid taken from diseased tissue. They suggested erythrocytes may be the origin of the aminopeptidase-like enzymes found in the human gingival fluid.

Squier and Johnson (1975) discussed the permeability of 
oral mucosa and pointed out that evidence indicated most substances passing across skin and oral mucosa move by simple diffusion and obey Fick's Iaw in which "the rate of penetration is directly proportional to the concentration of penetrant." They stated: (1) while connective tissue of skin or oral mucosa tends to limit the diffusion of non-polar molecules and macromolecules, it is not effective in limiting the penetration of polar substances, (2) the pathway by which leukocytes and presumably crevicular fluid leaves the tissue occurs principally at the junction of the oral sulcular epithelium and junctional epithelium, (3) sulcular epithelium was found to be permeable to substances with a molecular weight appraoching $1.0 \times 10^{6}$, and (4) exogenous substances enter the junctional epithelium by way of intercellular pathways since no intercellular barrier (comparable to membrane coating granules present in the oral epithelium which modify the intercellular substance limiting its permeability) exists in junctional epithelium. They concluded: (1) "Even in the intensely studied gingival area, we have little information concerning the intrinsic permeability of this tissue," (2) "Topical application of pharmacologically active substances may be ideal for controlling abnormal biological activity in oral mucosa, as effective doses can be far lower than when administered systemically," and (3) "there are large numbers of potentially useful drugs that have not yet been used in 
this way: their application awaits a better understanding 24 of mucosal permeability."

Golub and Kleinberg (1976) reviewed the literature concerning crevicular fluid and its implications in clinical periodontal therapy. They agreed with Alfano's (1974) theory that crevicular fluid was modulated by plaque by-product macromolecules; however, they proposed these substances increase fluid flow directly by altering the crevicular epithelium and the connective tissue cells. They pointed out more investigations should be directed towards the role of nonionized ammonia (alkaline $\mathrm{pH}$ of crevices, Kleinberg and Hall-1968, favors formation of this compound) and urea (Golub et al.-1971) in gingivitis, since gingival crevicular urea can serve as a substrate source for ammonia production. They noted the monitoring of gingival crevicular fluid flow can detect subclinical gingival pathology, quantify the severity of inflammation and monitor the response of the gingiva to periodontal therapy. They suggested collecting the gingival fluid on filter paper strips could also lead to the development of screening tests for systemic diseases by developing biochemical and microbiological analyses of gingival crevicular fluid constituents.

Suppipat (1976) investigated the use of the HAR-600 Gingival Crevice Fluid Meter (Harco Electronics ITD., winnipeg, Canada) in clinical research. He found measuring 
gingival fluid is a sensitive and objective method for evaluating the condition of the marginal gingiva (using the orifice method for fluid collection). His results indicated the HAR-600 $\mathrm{GCF}$ meter readings may vary with different strip location in the machine, with the viscosity of the fluid, and the room climate. It is recommended that each day the machine should be calibrated by quantitating known amounts of serum. He concluded: (1) using the orifice method (Löe and Holm-Pedersen-1965) none or very little gingival fluid was recovered from clinically healthy gingiva, (2) gingival inflammation has a stronger relationship with gingival fluid flow than with pocket depth (in agreement with Mann-1963), and (3) the orifice method reflected the progress of gingival wound healing as reported by other investigators using an intracrevicular sampling technique.

D. Clinical Literature

- Waerhaug (1960) histologically evaluated margins of restorations in relationship to the gingiva and found that gingival inflammation occurs from plaque and is not necessarily initiated by the nature of the material or its surface roughness. He stated subgingival margins contribute to the etiology of periodontitis; however, plaque microorganisms remaining in spaces between the crown and the preparation causes an inflammatory response. He concluded 
margin placement must involve consideration of:

caries rate, (2) predisposition for periodontitis, (3) oral hygiene, and (4) esthetics.

Morris (1962) discussed artificial crown contours in relation to gingival health. He refuted Amsterdam's et al. (1959) contention that buccal and lingual contours in crowns should deflect food over the crevice and stated that an artificial bulge is "an inaccurate view of gingivocoronal anatomy and physiology." Using bulges in crowns to protect the gingival crevice from food impaction produced crowns that were in excess of anything seen in Nature and caused, rather than prevented gingival pathology. He stated crown contours should permit proper muscle action and promote gingival health.

1. Löe (1962) stated investigations have shown "that any known type of dental restoration extending into the subgingival area causes damage to the periodontal tissues; either by providing possibilities for bacterial retention and/or by a direct irritational effect of the material per se." He suggested in view of the current knowledge of the pathogenesis and etiology of caries and periodontal disease the concept of 'extension for prevention' was no longer valid and required a "new theoretical basis for a combined prophylactic treatment of caries and periodontal disease." Using six dogs, Marcum (1967) prepared twelve teeth on 
each dog for crowns. Four were finished above, four even with and four below the gingival crest. The dogs were sacrificed and histological sections prepared from the crowned teeth. The results showed margins located at or even with the gingival crest caused the least inflammatory response while a slight to severe inflammatory reaction occurred from crowns with margins located above and below the gingival crest. He stated the poor gingival response to margins above the crest "may be due to plaque formation and adherence of food debris" and the results from crowns with margins even with the crest "may be due to a better marginal finish and a better crown contour that deflects food away from the gingival crevice."

Waerhaug (1968) suggested whenever possible, crowns should be finished above the gingival margin since bacterial plaque is retained in minute open spaces between the restoration and the tooth and "that many patients would be better off if bridges or partial dentures were not constructed."

Hount (1970) discussed the literature concerning gingival margin termination of crowns and stated, "when the gingival crevice is involved adequate preparation is probably the most important phase."

Berman (1973) stated, "the anatomy and physiology of the sulcus, coupled with refractory vision, present an 
insurmountable task in preparation" and pointed out

clinicians lack a standardized noninjurious technique for operating in the gingival sulcus. He described a beveled shoulder preparation technique which provided the proper space for a gold collar marginal termination without injury to the soft tissue.

Trivedi and Talim (1973) placed polished or unpolished amalgam, silicate cement, acrylic resin, or gold alloy restorations in class $V$ preparations on fifty-four human teeth scheduled for removal in orthodontic treatment cases. They were clinically and histologically evaluated after sixty days. Their results showed no clinical changes in the gingiva adjacent to all the restorations; however, histological evidence of maximal inflammation occurred with tissue adjacent to silicate cements and acrylic resin restorations. No inflammation was found in tissue associated with the gold alloy restorations. Thirty-three per cent of all tissue samples did not show evidence of tissue pathoses regardless of the restorative material involved. They concluded "the gingival response appeared to be caused by chemical injury, unpolished restorative materials, poor marginal adaptation, and inadequate oral hygiene."

Volchnasky et al. (1974) studied surface roughness of enamel, cementum, amalgam, gold inlay, porcelain-fused-togold and calculus utilizing a scanning electron microscope and 
a Taylor-Hobson Talysurf model 3 surface roughness testing machine. Five numberical assements were made and five different orders of roughness were found, with enamel being the only constantly assessable surface. They concluded, "enamel is probably the smoothest and most acceptable surface in the mouth, and all natural and restored surfaces should be compared to it."

Mörmann (1974) investigated the effects of polished or roughened well-adapted subgingival (at least one millimeter into the sulcus) inlay margins on the gingival fluid rate (ninhyarin staining technique) and plaque formation (scoring method after Löe and Silness-1967). The proximal inlays were placed in contralateral teeth on eight human subjects. Their results showed the mean gingival flow from gingival tissue next to non-restored teeth was significantly lower than the amount of fluid collected from tissue next to restored teeth, regardless of a rough or polished surface texture. It was also found a significantly larger amount of plaque formed on roughened inlay surfaces compared to polished surfaces. Their conclusion was "that even perfectly adapted and well polished proximal gold inlays cause gingival inflammation."

Nemetz (1974) described specific instrumentation procedures for fixed prosthetic fabrication designed to minimize trauma to gingival tissue. It involved judicious 
use of the electrosurgery, proper bevel placement, use of aluminum sulfate for retraction procedures and properly contoured provisional restorations. He emphasized healthy gingival tissue must be present prior to final tooth preparation.

Ramf jord et al. (1974) reviewed a longitudinal study (covering three years) completed at the University of Oslo concerning margin location of bridge abutments in relation to the gingival crest. The result showed: (1) more periodontal pathosis was found on teeth which had subgingival margins, (2) locating margins subgingivally did not $r$ necessarily give the anticipated protection against caries, (3) provisional restorations left in the mouth for long periods of time will cause gingival recession, and (4) removal of the sulcular epithelium during any type of procedure will increase the potential for introduction of foreign material by an increased sulcular epithelium permeability.

Newcomb (1974) investigated the degree of gingival inflammation in relation to subgingival crown margins placed at varying levels within the sulcus and compared this to the contralateral non-restored teeth on the same patients. Fifty-nine patients with thirty-four porcelain jacket crowns and thirty-two porcelain-fused-to-metal anterior veneer crowns were assessed after approximately eight months using the Gingival Index and the Plaque Index (Löe and Silness-1967), 
mesuring the gingival crevice depth and the distance between the gingival crest and the subgingival crown magin. Their conclusions were: (1) "the nearer a subgingival crown margin approaches the base of the gingival crevice, the more likely it is that sever gingival inflammation will occur, and (2) "the least inflammation is observed when subgingival crown margins are placed at the gingival crest or just into the gingival crevice.

Strauss et al.(1975) utilized the Gingival Crevice Meter (Harco) to compare subclinical inflammatory changes under major connectors of mandibular partial dentures. Their results showed changes in crevicular fluid flow with no changes in pocket depth or Gingival Index (Iöe and Silness1967). They concluded "that the removable partial denture components can modify the crevicular flow of adjacent gingival crevices."

Burch (1975) advocated that margins of restorations should be supragingival unless there is a specific indication for subgingival placement. He emphasized the development of proper buccal, lingual, proximal and transitional line contours in restorations in order to maintain the health of the gingiva.

Larato (1975) investigated the frequency of pathological pocket depths associated with subgingival margins and the frequency of tooth brushing on 111 male veteran patients. His results showed: (1) restored teeth with subgingival margins 
had pockets $47 \%$ deeper than those of non-restored teeth, (2) fifty-five per cent of restored teeth with subgingival margins had greater association with pathologic pocket depths than for non-restored teeth, and (3) pocket depth increased with the age of the patient (both restored and non-restored teeth).

Maruyama et al. (1976) studied the morphologic changes of capillaries in human gingiva adjacent to teeth with complete crowns (porcelain-bonded-to-gold). Their results showed more than one-fourth of the capillary loops nearest to complete crowns showed dilation (a capillary diameter greater than $20 \mathrm{u}$ ). Dilation and complex capillary loops were found in gingiva next to crows classified clinically normal.

Mahajan (1976) did histological evaluations of interdental papillary tissue adjacent to full coverage restorations and non-restored teeth. Her findings showed: clinically normal gingiva from non-rostored teeth had few inflammatory cells, (2) normal gingiva adjacent to restored teeth had more inflammatory cells and dilated blood vessels, (3) inflamed gingiva adjacent to restored teeth had heavy infiltration of inflammatory cells and dilated blood vessels, (4) loss of collagen fibers occurred around blood vessels where inflammation was present, and (5) the mitotic index of squamous epithelium increased as associated with full coverage restorations. 


\section{MATERIALS AND METHOD}

Patients participating in this project were selected from those being treated at Loyola Dental School clinic. A consent form (see Appendix A) describing the procedure was signed by each patient and a brief medical and dental history completed (none of the patients had a history of systemic disease). Thirty-two adult patients between the ages of twelve and sixty (mean age of 33.9 years) were selected and their marginal gingiva in the area of collection assessed (after Löe and Silness-1967, see below) and the depth of the sulcus measured (see Figure 4) and recorded (see Appendix).

\section{Gingival Index - Löe and Silness}

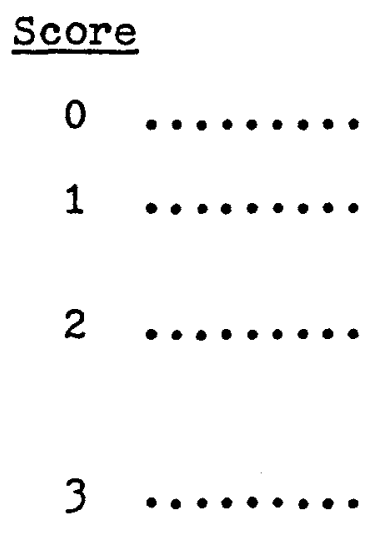

Clinical Findings

Absence of Inflammation.

Mild Inflammation: Slight change in color and little change in texture.

Moderate Inflammation: Moderate glazing, redness, edema and hypertrophy. Bleeding on pressure.

Severe Inflammation: Marked redness and hypertrophy; tendency to spontaneous bleeding; ulceration.

Teeth selected for measuring gingival crevicular fluid included from maxillary right second premolar to maxillary 
left premolar. Comparison of crevicular fluid volume between non-restored gingival margins were done on the same patient; thus, patients with a full coverage restoration on one side and no restoration on the contralateral tooth (e.g. maxillary right lateral with a crown and maxillary left lateral with no restoration) were used for this study. All restorations had subgingival margins. Two measurements, mesial-buccal and distal-buccal near the interdental papillae area, of each tooth (restored and non-restored) were taken; therefore, a total of seventy fluid volume measurements were taken (see Table 1). All measurements were taken by the same investigator. The collection technique followed the method suggested by the manufacturer (Harco Electronics Limited, Winnipeg, Canada; see Figures 8 and 9) and the findings of Borden (1974) in regard to the use of this particular instrument. The collection technique is as follows:

1. Region to be examined is dried and isolated with sterile cotton rolls.

2. A sterile dry filter paper strip (Periopaper, Harco, $1.5 \mathrm{~mm} \times 13 \mathrm{~mm}$; see Figure 5) is placed at the entrance to the gingival sulcus orfice (after Löe and Holm-Pedersen-1965; see Figures 1 and 8 ) for three seconds to empty the crevicular pool. This filter strip is removed and discarded. 
3. After a twenty-seven seconds interval, another sterile dry filter paper strip is placed at the sulcus orfice for three seconds. The total elapsed time is thirty seconds.

4. The filter paper strip is immediately placed between the recording sensors so the entire moistened area of the filter strip is in contact with the sensors (the filter paper strip is inserted to the line marked on each filter strip; see Figures 6,7, and 9).

5. With the switch on the no hold mode, the digital read-out value rises to a maximum and then decreases. The highest numerical reading is recorded. The digital numerical values are converted to fluid volume (microliters) by dividing the readings by 200 (e.g. a digital reading of $20=0.10 \mu \mathrm{l}$ )

6. After each measurement, the sensors are dried with a sterile cotton roll.

Information from each data sheet was compiled into a single table (see Table 1) and the mean values for all measurements computed. Crevicular fluid volume values were subjected to analysis of variance to determine if a statistically significant difference existed between the fluid volume of restored teeth and non-restored teeth. 


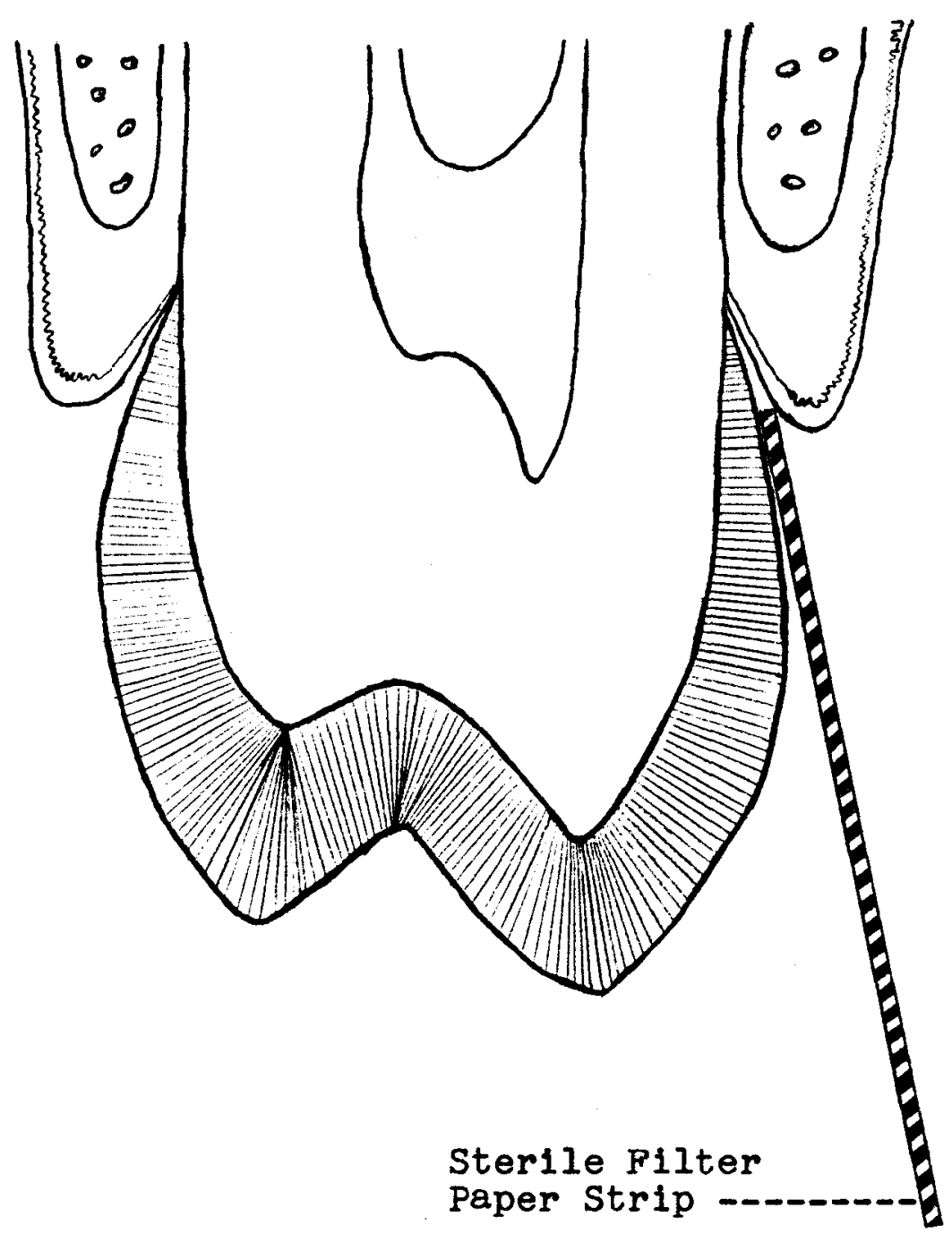

Figure 1. Orfice Method for Crevicular Fluid Sampling Technique (After Löe and Holm-Pedersen-1965) 


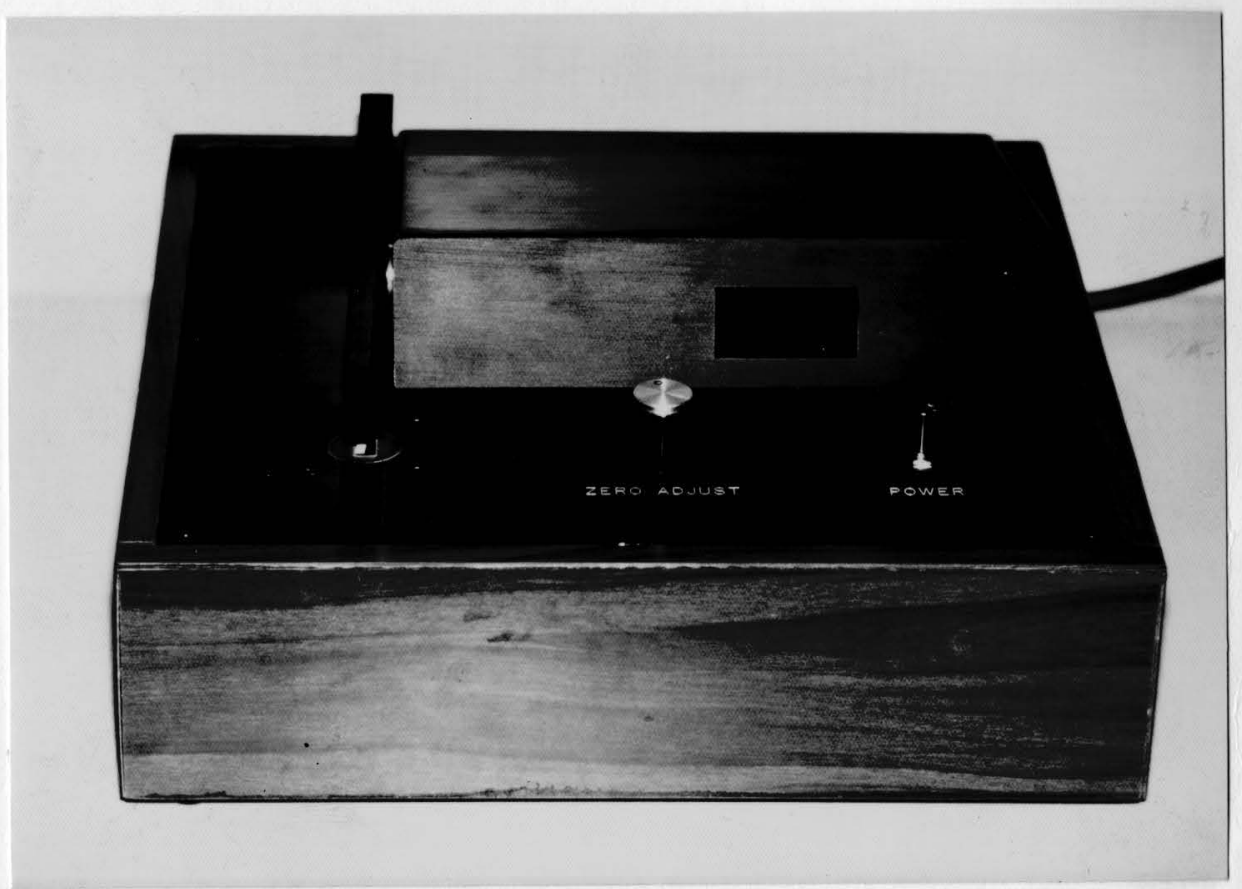

Figure 2. Gingival Crevicular Fluid Meter Model HR-600 (Harco Electronics LTD, Winnepeg, Canada). 


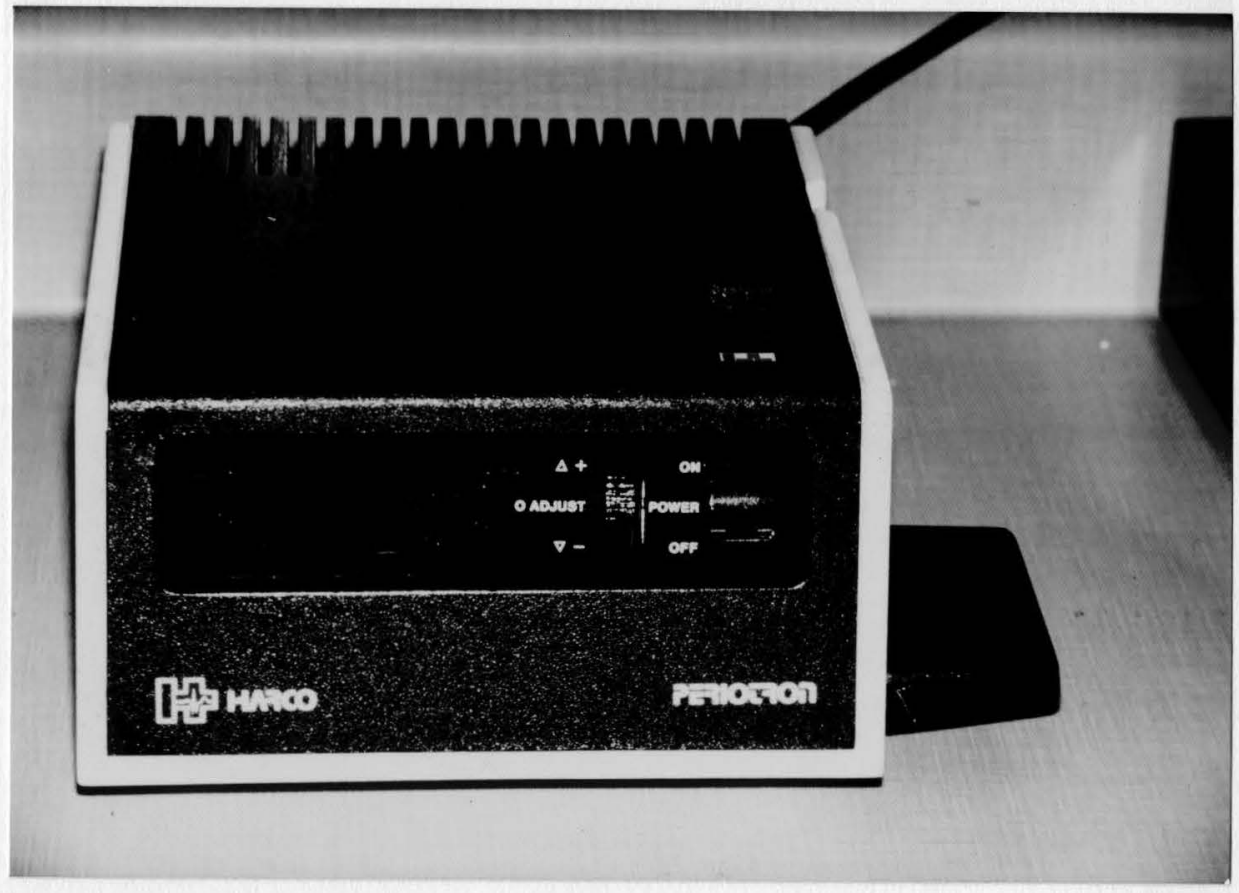

Figure 3. Periotror ${ }^{\circledR}$ (Clinical GCF Meter - Harco Electronics ITD, Winnepeg, Canada). 


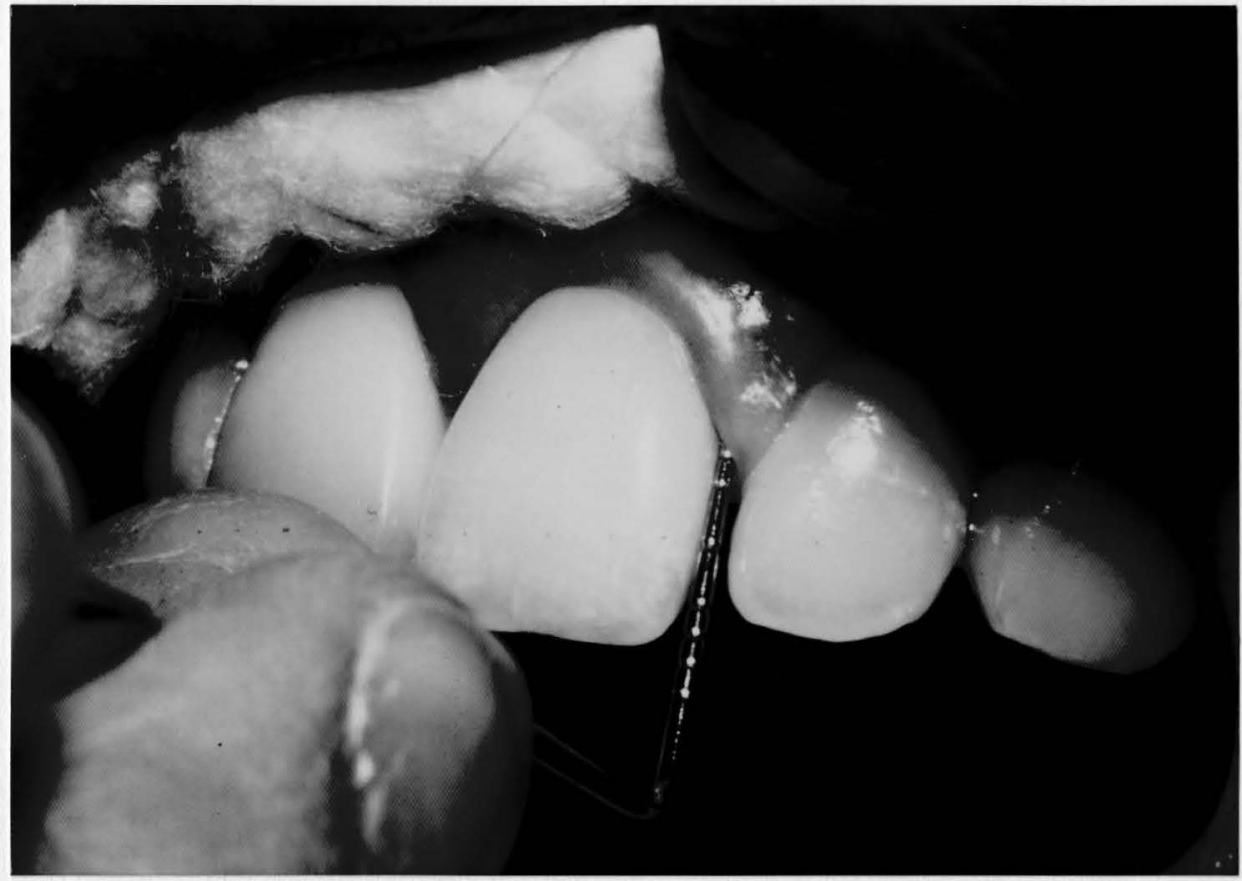

Figure 4. Measuring Sulcus Depth (After collecting GCF). 


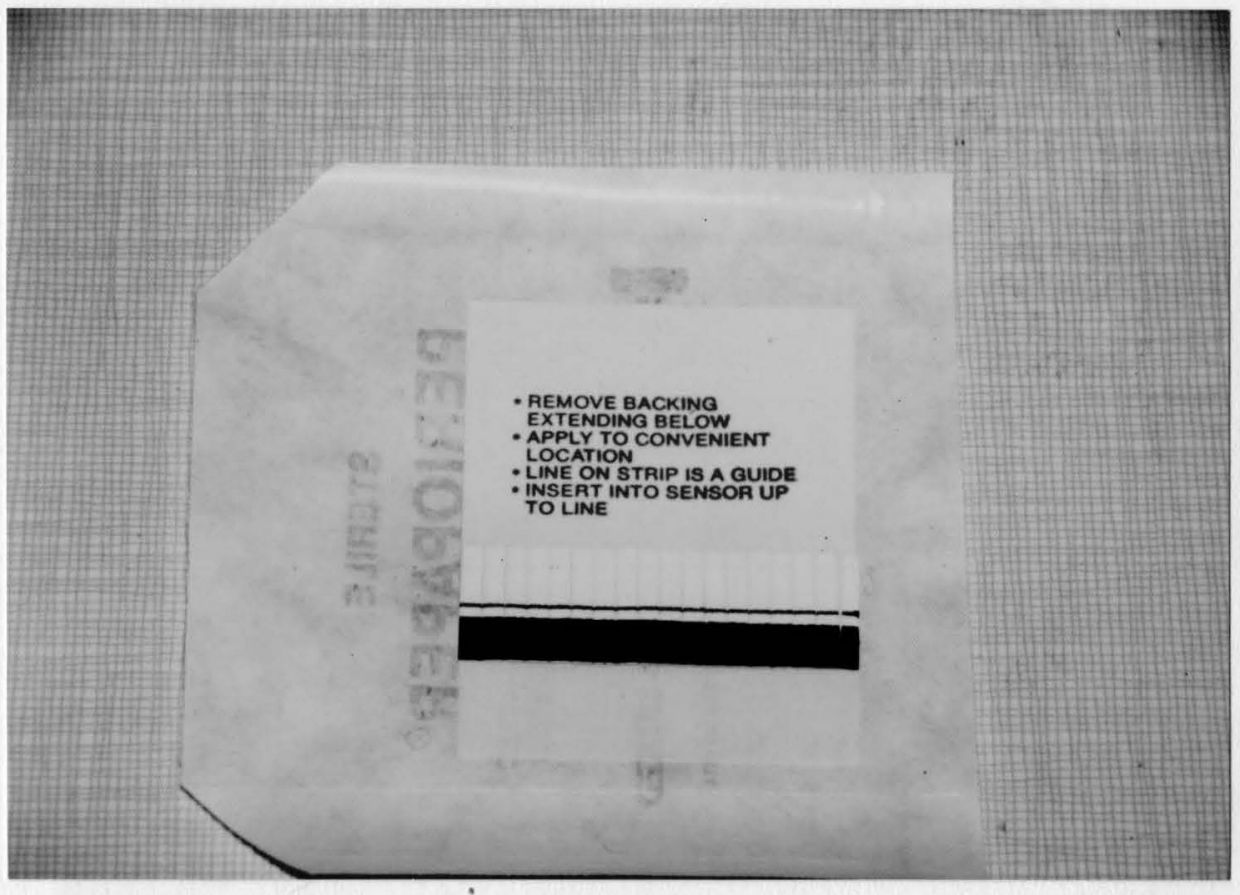

Figure 5. Sterile Filter Paper Strips (Periopaper Harco Electronics ITD, Winnepeg, Canada). 


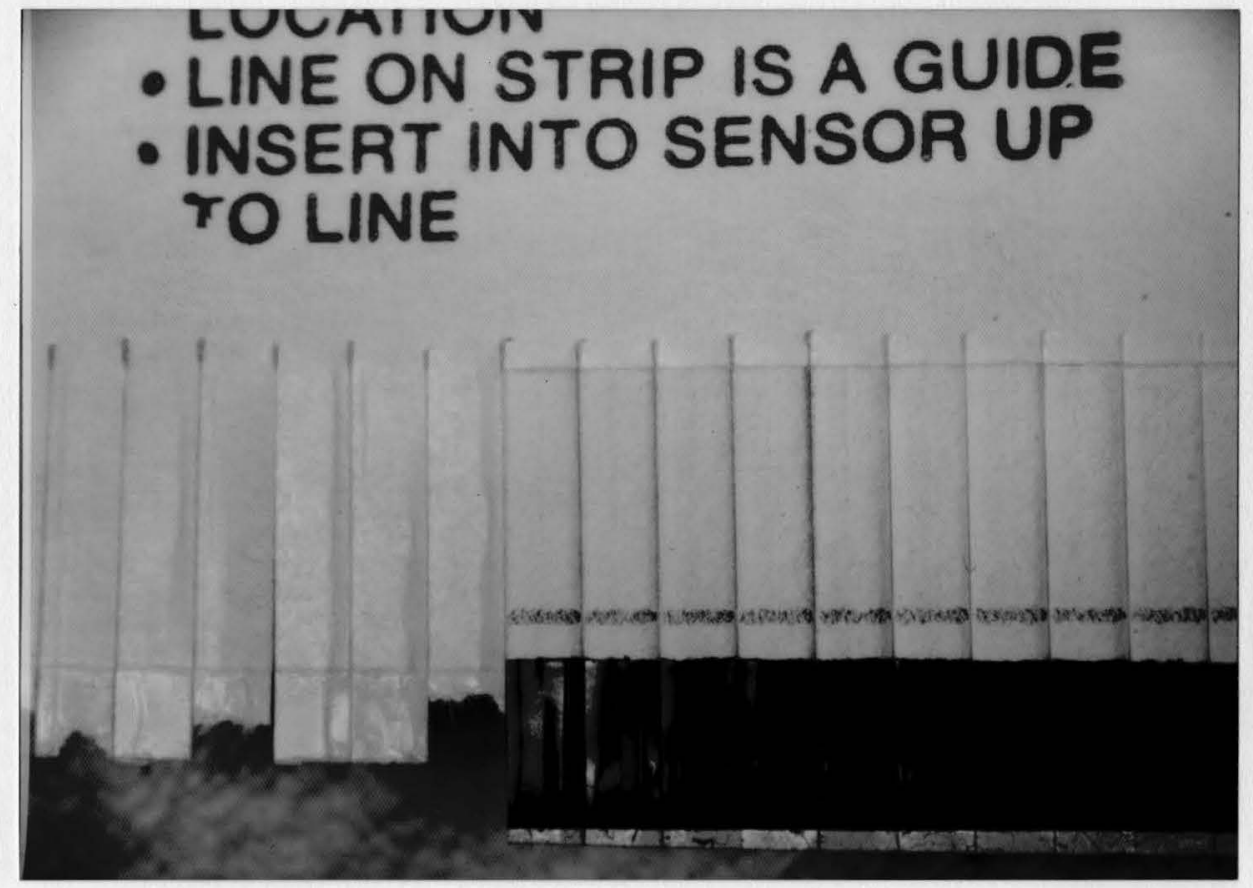

Figure 6. Holding Card for Filter Paper Strips (Periopaper - Harco Electronics LTD, Winnepeg, Canada). 


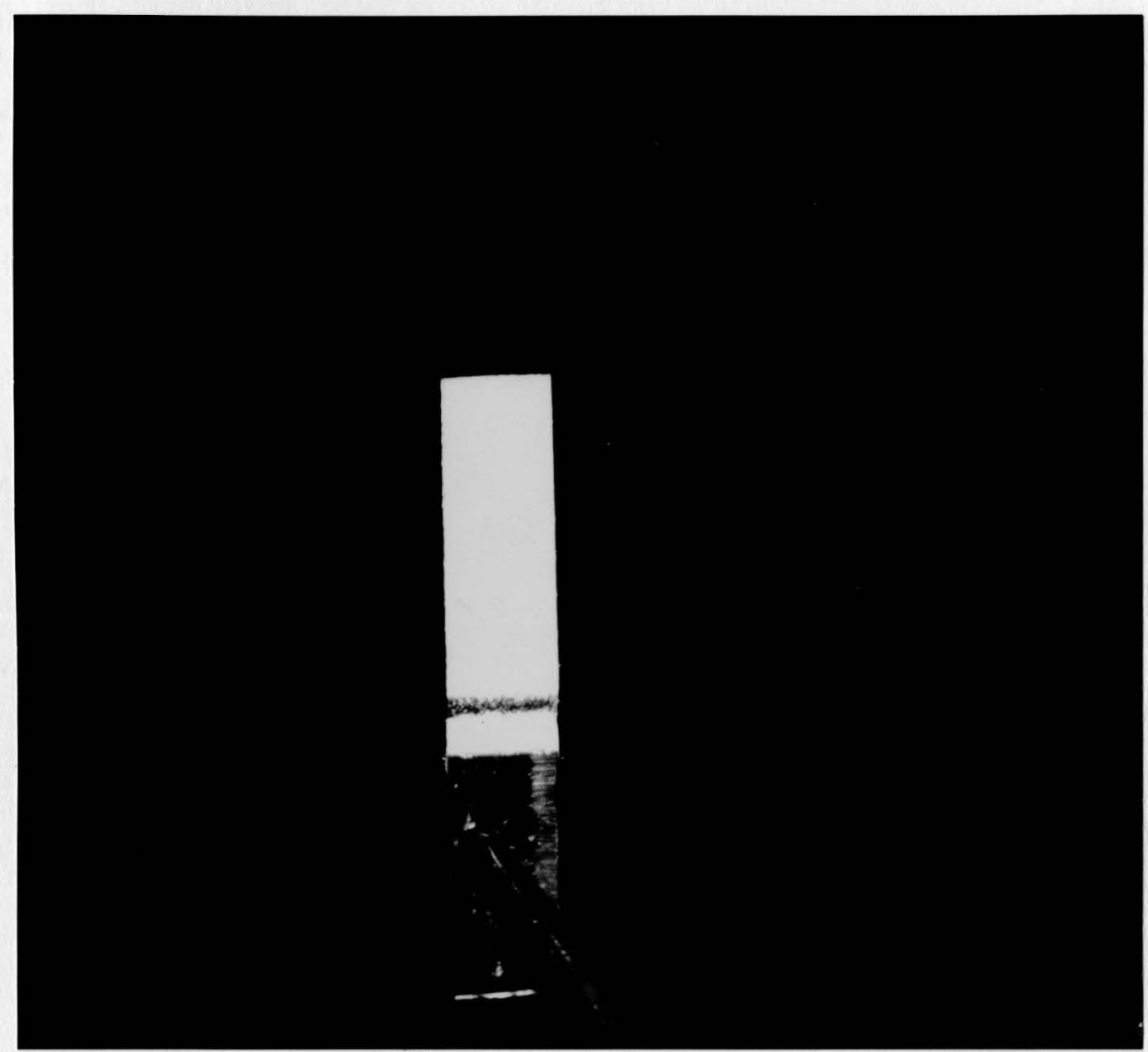

Figure 7. Filter Paper Strip Prior to Collection of Crevicular Fluid. 


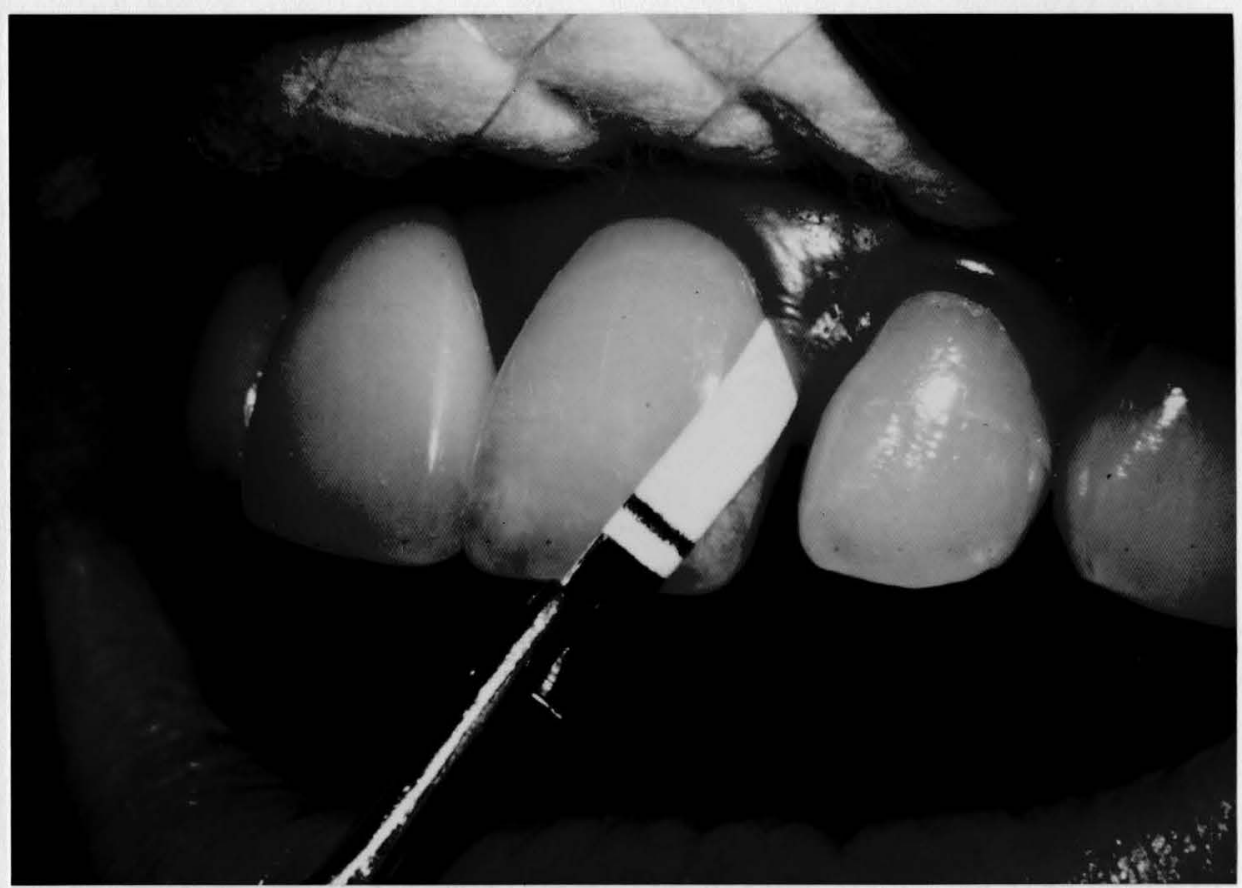

Figure 8. Gingival Crevicular Fluid Collection Technique. 


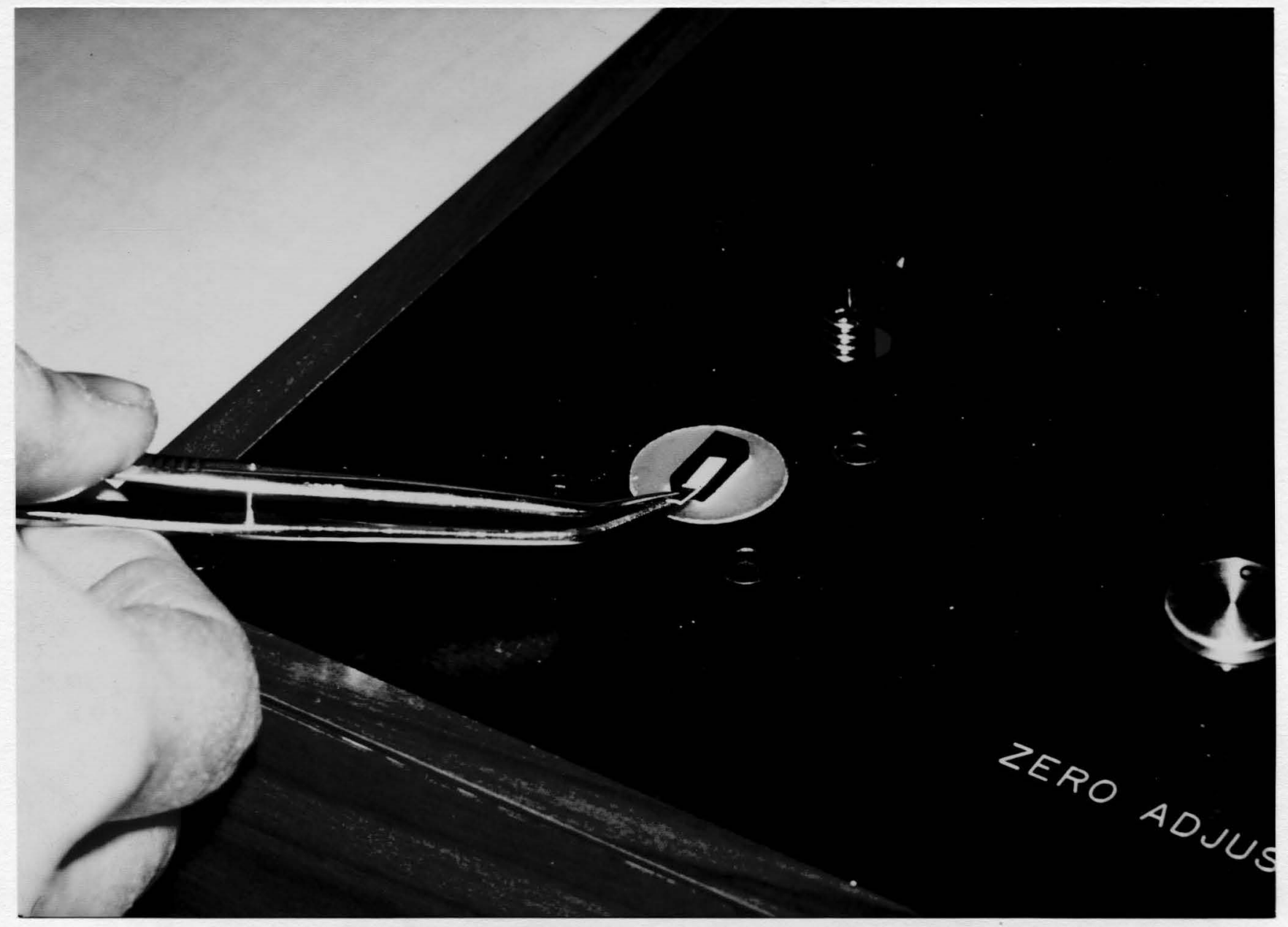

Figure 9. Placing Filter Paper Strip Between Recording Sensors. 


\section{EXPERIMENTAL RESULTS}

Table one is the compiled data from individual data sheets (see Appendix A) listing the patient's number, sex, age, teeth involved in the collection, the restorative material and the recorded values for pocket depth (mm), Gingival Index, and crevicular fluid volume (instrument readings and microliters).

Table two is the analysis of variance table for the crevicular fluid volumes showing an $F$ ratio of 17.1 indicating a highly significant $(P<.001)$ difference between the crevicular fluid volume from restored teeth compared to non-restored teeth.

Table three summarizes the means values of Gingival Index, pocket depth, and the gingival crevicular fluid readings collected from restored and non-restored teeth. The mesial crevicular fluid readings from restored teeth and non-restored teeth were lower than the distal readings (restored, $m=6.9, d=7.3$; non-restored, $m=3.2, d=3.8$ ). The crevicular fluid volumes from the restored teeth were approximately twice the values obtained from the contralateral non-restored teeth.

Table four illustrates the frequency distribution of restorations and the percentage distribution of the types 45 
of restorative material. Listed below in decreasing order is the distribution of restored teeth.

\begin{tabular}{rrrr}
$\begin{array}{c}\text { Tooth } \\
\#\end{array}$ & $\begin{array}{c}\text { No. of } \\
\text { Teeth }\end{array}$ & \multicolumn{1}{c}{$\begin{array}{l}\text { \% of To. Te } \\
\text { No. Te }\end{array}$} \\
1. & 8 & 7 & 20.0 \\
2. & 5 & 6 & 17.1 \\
3. & 9 & 6 & 17.1 \\
4. & 4 & 5 & 14.3 \\
5. & 10 & 4 & 11.4 \\
6. & 6 & 3 & 8.5 \\
7. & 7 & 1 & 2.9 \\
8. & 11 & 1 & 2.9 \\
9. & 12 & 1 & 2.9 \\
10. & 13 & 1 & 2.9
\end{tabular}

The following lists in decreasing order the frequency distribution of restorative materials:

$$
\begin{aligned}
& \text { No. of } \$ \text { of Total } \\
& \text { Teeth No. Teeth }
\end{aligned}
$$

Porcelain-Fused-

to-Gold

Acrylic-Processed-

to-Gold

Porcelain Jacket

Crown

Acrylic Crown

Full Gold Crown
$15 \quad 42.9$

$10 \quad 28.6$

$8 \quad 22.9$

$\begin{array}{ll}1 & 2.8\end{array}$

Total $\frac{1}{35} \quad \frac{2.8}{100.0}$ 
Patient

Tooth Rest've M-Fluid Ging'l Pocket D-Fluid Ging'l Pocket Fluid

Number Age Sex \# Mat'ial Volume Index Depth Volume Index Depth Vol.Ave. $\mu l$

\begin{tabular}{|c|c|c|c|c|c|c|c|c|c|c|c|c|}
\hline 1 & 37 & $\mathrm{~F}$ & $\begin{array}{r}4 \\
13\end{array}$ & $\mathrm{CC}$ & $\begin{array}{r}3 \\
12\end{array}$ & $\begin{array}{l}0 \\
1\end{array}$ & $\begin{array}{l}2 \\
2\end{array}$ & $\begin{array}{l}11 \\
1.0\end{array}$ & $\begin{array}{l}0 \\
1\end{array}$ & $\begin{array}{l}2 \\
2\end{array}$ & $\begin{array}{r}7.0 \\
11.0\end{array}$ & $\begin{array}{l}.0350 \\
.0550\end{array}$ \\
\hline 2 & 22 & $\mathbf{F}$ & $\begin{array}{l}9 \\
8\end{array}$ & CC & $\begin{array}{l}2 \\
1\end{array}$ & $\begin{array}{l}0 \\
0\end{array}$ & $\begin{array}{l}2 \\
2\end{array}$ & $\begin{array}{l}1 \\
1\end{array}$ & $\begin{array}{l}0 \\
0\end{array}$ & $\begin{array}{l}2 \\
2\end{array}$ & $\begin{array}{l}1.5 \\
1.0\end{array}$ & $\begin{array}{l}.0075 \\
.0050\end{array}$ \\
\hline 3 & 43 & $F$ & $\begin{array}{r}12 \\
5\end{array}$ & AFC & $\begin{array}{l}? \\
7\end{array}$ & $\begin{array}{l}0 \\
0\end{array}$ & $\begin{array}{l}3 \\
3\end{array}$ & $\begin{array}{r}3 \\
1.7\end{array}$ & $\begin{array}{l}0 \\
0\end{array}$ & $\begin{array}{l}3 \\
3\end{array}$ & $\begin{array}{r}5.0 \\
12.0\end{array}$ & $\begin{array}{l}.0250 \\
.0600\end{array}$ \\
\hline 4 & 27 & $M$ & $\begin{array}{l}8 \\
9\end{array}$ & PJC & $\begin{array}{l}6 \\
6\end{array}$ & $\begin{array}{l}0 \\
1\end{array}$ & $\begin{array}{l}2 \\
2\end{array}$ & $\frac{1}{7}$ & $\begin{array}{l}0 \\
1\end{array}$ & $\begin{array}{l}2 \\
2\end{array}$ & $\begin{array}{l}3.5 \\
6.5\end{array}$ & $\begin{array}{l}.0175 \\
.0325\end{array}$ \\
\hline 5 & 26 & M & $\begin{array}{r}12 \\
5\end{array}$ & APC & $\begin{array}{l}5 \\
9\end{array}$ & $\begin{array}{l}0 \\
0\end{array}$ & $\begin{array}{l}2 \\
2\end{array}$ & $\begin{array}{r}6 \\
10\end{array}$ & $\begin{array}{l}0 \\
0\end{array}$ & $\begin{array}{l}2 \\
2\end{array}$ & $\begin{array}{l}5.5 \\
9.5\end{array}$ & $\begin{array}{l}.0275 \\
.0475\end{array}$ \\
\hline 6 & 52 & $\mathbf{F}$ & 13 & AFC & $\begin{array}{r}99 \\
14\end{array}$ & $\begin{array}{l}0 \\
1\end{array}$ & $\begin{array}{l}3 \\
3\end{array}$ & $\begin{array}{l}4 \\
9\end{array}$ & $\begin{array}{l}0 \\
1\end{array}$ & $\begin{array}{l}3 \\
3\end{array}$ & $\begin{array}{r}6.5 \\
11.5\end{array}$ & $\begin{array}{l}.0325 \\
.0575\end{array}$ \\
\hline 7 & 45 & $F$ & $\begin{array}{r}7 \\
10\end{array}$ & $\mathrm{CC}$ & $\begin{array}{l}6 \\
8\end{array}$ & $\begin{array}{l}0 \\
0\end{array}$ & $\begin{array}{l}2 \\
2\end{array}$ & $\begin{array}{l}4 \\
4\end{array}$ & $\begin{array}{l}0 \\
0\end{array}$ & $\begin{array}{l}2 \\
2\end{array}$ & $\begin{array}{l}5.0 \\
6.0\end{array}$ & $\begin{array}{l}.0250 \\
.0300\end{array}$ \\
\hline 8 & 33 & $M$ & $\begin{array}{r}13 \\
4 \\
12 \\
5\end{array}$ & $\begin{array}{l}\mathrm{CC} \\
\mathrm{CC}\end{array}$ & $\begin{array}{l}1 \\
7 \\
1 \\
3\end{array}$ & $\begin{array}{l}0 \\
2 \\
0 \\
1\end{array}$ & $\begin{array}{l}2 \\
3 \\
3 \\
2\end{array}$ & $\begin{array}{r}3 \\
13 \\
11 \\
7\end{array}$ & $\begin{array}{l}0 \\
2 \\
0 \\
2\end{array}$ & $\begin{array}{l}2 \\
3 \\
3 \\
3\end{array}$ & $\begin{array}{r}2.0 \\
10.0 \\
6.0 \\
5.0\end{array}$ & $\begin{array}{l}.0100 \\
.0500 \\
.0300 \\
.0250\end{array}$ \\
\hline 9 & 48 & $F$ & 13 & APC & 20 & $\begin{array}{l}1 \\
2\end{array}$ & $\begin{array}{l}2 \\
2\end{array}$ & $\begin{array}{l}11 \\
11\end{array}$ & $\frac{1}{2}$ & $\begin{array}{l}4 \\
4\end{array}$ & $\begin{array}{r}6.0 \\
15.5\end{array}$ & $\begin{array}{l}.0300 \\
.0780\end{array}$ \\
\hline 10 & 48 & $F$ & $\begin{array}{l}9 \\
8\end{array}$ & PJC & $\begin{array}{l}1 \\
5\end{array}$ & $\begin{array}{l}0 \\
1\end{array}$ & $\begin{array}{l}3 \\
3\end{array}$ & $\begin{array}{r}0 \\
10\end{array}$ & $\begin{array}{l}0 \\
1\end{array}$ & $\begin{array}{l}3 \\
2\end{array}$ & $\begin{array}{l}1.0 \\
7.5\end{array}$ & $\begin{array}{l}.0050 \\
.0375\end{array}$ \\
\hline 11 & 24 & $F$ & $\begin{array}{l}9 \\
8\end{array}$ & PJC & $\frac{1}{6}$ & $\begin{array}{l}0 \\
0\end{array}$ & $\begin{array}{l}2 \\
2\end{array}$ & $\begin{array}{r}1 \\
11\end{array}$ & $\begin{array}{l}0 \\
0\end{array}$ & $\begin{array}{l}2 \\
2\end{array}$ & $\begin{array}{l}1.0 \\
8.5\end{array}$ & $\begin{array}{l}.0050 \\
.0425\end{array}$ \\
\hline 12 & 56 & $M$ & $\begin{array}{r}12 \\
5\end{array}$ & AFC & $\begin{array}{l}7 \\
3\end{array}$ & $\begin{array}{l}1 \\
1\end{array}$ & $\begin{array}{l}3 \\
3\end{array}$ & $\begin{array}{r}? \\
10\end{array}$ & $\begin{array}{l}1 \\
1\end{array}$ & $\begin{array}{l}3 \\
3\end{array}$ & $\begin{array}{l}7.0 \\
6.5\end{array}$ & $\begin{array}{l}.0350 \\
.0325\end{array}$ \\
\hline
\end{tabular}

Table 1

Compiled Data 


\section{patient}

Tooth Rest've M-Fluid Ging'

Number Age Sex \# Mat'ial Volume Index

\section{Pocket D}

\begin{tabular}{|c|c|c|c|c|c|c|c|c|}
\hline 13 & 24 & $F$ & $\begin{array}{l}8 \\
9\end{array}$ & PJC & $\begin{array}{l}4 \\
5\end{array}$ & $\begin{array}{l}0 \\
0\end{array}$ & $\begin{array}{l}2 \\
2\end{array}$ & $\begin{array}{l}4 \\
6\end{array}$ \\
\hline 14 & 55 & $F$ & $\begin{array}{r}13 \\
4 \\
12 \\
5\end{array}$ & $\begin{array}{l}\text { FGC } \\
\text { AFC }\end{array}$ & $\begin{array}{r}5 \\
11 \\
3 \\
8\end{array}$ & $\begin{array}{l}0 \\
1 \\
0 \\
1\end{array}$ & $\begin{array}{l}2 \\
2 \\
2 \\
2\end{array}$ & $\begin{array}{l}4 \\
6 \\
4 \\
5\end{array}$ \\
\hline 15 & 26 & $\mathrm{~F}$ & $\begin{array}{r}5 \\
12\end{array}$ & AFC & $\frac{1}{5}$ & $\begin{array}{l}1 \\
0\end{array}$ & $\begin{array}{l}3 \\
2\end{array}$ & $\begin{array}{l}5 \\
4\end{array}$ \\
\hline 16 & 25 & $M$ & $\begin{array}{l}8 \\
9\end{array}$ & $\mathrm{CC}$ & $\begin{array}{l}6 \\
3\end{array}$ & $\begin{array}{l}0 \\
0\end{array}$ & $\begin{array}{l}2 \\
3\end{array}$ & $\begin{array}{l}5 \\
7\end{array}$ \\
\hline 17 & 13 & $F$ & $\begin{array}{l}8 \\
9\end{array}$ & PJC & $1 \frac{1}{5}$ & $\begin{array}{l}0 \\
2\end{array}$ & $\begin{array}{l}1 \\
2\end{array}$ & 20 \\
\hline 18 & 31 & $M$ & $\begin{array}{r}12 \\
5\end{array}$ & $\mathrm{AFC}$ & $\begin{array}{r}2 \\
11\end{array}$ & $\begin{array}{l}1 \\
1\end{array}$ & $\begin{array}{l}3 \\
3\end{array}$ & $\begin{array}{r}3 \\
11\end{array}$ \\
\hline 19 & 19 & $\mathbf{F}$ & $\begin{array}{l}9 \\
8\end{array}$ & PJC & $\begin{array}{l}2 \\
4\end{array}$ & $\begin{array}{l}0 \\
1\end{array}$ & $\begin{array}{l}3 \\
3\end{array}$ & $\begin{array}{l}2 \\
2\end{array}$ \\
\hline 20 & 12 & $F$ & $\begin{array}{l}9 \\
8\end{array}$ & A & $\begin{array}{l}5 \\
9\end{array}$ & $\begin{array}{l}0 \\
1\end{array}$ & $\begin{array}{l}3 \\
3\end{array}$ & $\begin{array}{l}8 \\
8\end{array}$ \\
\hline 21 & 1.8 & $\mathrm{~F}$ & $\begin{array}{r}10 \\
7\end{array}$ & $\mathrm{AFC}$ & 14 & $\begin{array}{l}0 \\
1\end{array}$ & $\begin{array}{l}2 \\
4\end{array}$ & $\begin{array}{l}4 \\
9\end{array}$ \\
\hline 22 & 17 & $M$ & $\begin{array}{l}8 \\
9\end{array}$ & PJC & $\begin{array}{r}0 \\
12\end{array}$ & $\begin{array}{l}0 \\
1\end{array}$ & $\begin{array}{l}3 \\
4\end{array}$ & 13 \\
\hline 23 & 18 & $F$ & 1.3 & $\triangle F C$ & $\begin{array}{l}6 \\
7\end{array}$ & $\begin{array}{l}0 \\
1\end{array}$ & $\begin{array}{l}2 \\
4\end{array}$ & $\begin{array}{r}6 \\
13\end{array}$ \\
\hline 24 & 21 & $M$ & $\begin{array}{r}11 \\
6\end{array}$ & $\mathrm{CC}$ & $\begin{array}{r}1.4 \\
0\end{array}$ & $\begin{array}{l}0 \\
0\end{array}$ & $\begin{array}{l}2 \\
2\end{array}$ & $\begin{array}{l}6 \\
0\end{array}$ \\
\hline
\end{tabular}

ing'l Pocket Fluid
Index Depth Vol.Ave. $\mu l$

$\begin{array}{llrl}0 & 2 & 4.0 & .0200 \\ 0 & 2 & 5.5 & .0275 \\ 0 & 2 & 4.5 & .0225 \\ 1 & 2 & 8.5 & .0425 \\ 0 & 2 & 3.5 & .0175 \\ 1 & 3 & 6.5 & .0325 \\ 1 & 4 & 3.0 & .0150 \\ 0 & 2 & 4.5 & .0225 \\ 0 & 4 & 5.5 & .0275 \\ 1 & 2 & 5.0 & .0250 \\ 0 & 1 & 1.0 & .0050 \\ 2 & 2 & 17.5 & .0875 \\ 1 & 3 & 2.5 & .0125 \\ 1 & 3 & 11.0 & .0550 \\ 0 & 3 & 2.0 & .0100 \\ 1 & 3 & 3.0 & .0150 \\ 0 & 3 & 6.5 & .0320 \\ 1 & 3 & 8.5 & .0425 \\ 0 & 2 & 2.5 & .0125 \\ 1 & 4 & 12.5 & .0625 \\ 1 & 4 & 3.0 & .0150 \\ 1 & 4 & 12.5 & .0625 \\ 0 & 2 & 6.0 & .0300 \\ 1 & 4 & 10.0 & .0500 \\ 0 & 2 & 10.0 & .0500 \\ 0 & 2 & 0.0 & .0000\end{array}$


patient

Number Age Sex
Tooth Rest've M-Fluid Ging'I Pocket D-Fluid Ging'I Pocket Fluid

\# Mat'ial Volume Index Depth Volume Index Depth Vol.Ave. $\mu l$

\begin{tabular}{|c|c|c|c|c|c|c|c|c|c|c|c|c|}
\hline 25 & 32 & M & $\begin{array}{l}9 \\
8\end{array}$ & CC & $\begin{array}{l}4 \\
7\end{array}$ & $\begin{array}{l}0 \\
1\end{array}$ & $\begin{array}{l}2 \\
3\end{array}$ & $\frac{1}{6}$ & $\begin{array}{l}0 \\
1\end{array}$ & $\begin{array}{l}2 \\
3\end{array}$ & $\begin{array}{l}2.5 \\
6.5\end{array}$ & $\begin{array}{l}.0125 \\
.0325\end{array}$ \\
\hline 26 & 58 & $M$ & 11 & CC & $\begin{array}{r}0 \\
11\end{array}$ & $\begin{array}{l}0 \\
1\end{array}$ & $\begin{array}{l}3 \\
3\end{array}$ & $\begin{array}{l}6 \\
8\end{array}$ & $\begin{array}{l}0 \\
0\end{array}$ & $\begin{array}{l}3 \\
3\end{array}$ & $\begin{array}{l}6.0 \\
9.5\end{array}$ & $\begin{array}{l}.0300 \\
.0475\end{array}$ \\
\hline 27 & 47 & $F$ & $\begin{array}{r}11 \\
6\end{array}$ & $C C$ & $\begin{array}{l}0 \\
0\end{array}$ & $\begin{array}{l}0 \\
1\end{array}$ & $\begin{array}{l}2 \\
3\end{array}$ & $\begin{array}{l}0 \\
1\end{array}$ & $\begin{array}{l}0 \\
1\end{array}$ & $\begin{array}{l}2 \\
3\end{array}$ & $\begin{array}{l}0.0 \\
1.0\end{array}$ & $\begin{array}{l}.0000 \\
.0050\end{array}$ \\
\hline 28 & 63 & $\mathrm{~F}$ & $\begin{array}{r}7 \\
10 \\
9 \\
8\end{array}$ & $\begin{array}{l}\mathrm{CC} \\
\mathrm{CC}\end{array}$ & $\begin{array}{l}0 \\
0 \\
2 \\
2\end{array}$ & $\begin{array}{l}0 \\
0 \\
0 \\
0\end{array}$ & $\begin{array}{l}3 \\
3 \\
3 \\
3\end{array}$ & $\begin{array}{l}4 \\
2 \\
0 \\
0\end{array}$ & $\begin{array}{l}0 \\
0 \\
0 \\
0\end{array}$ & $\begin{array}{l}3 \\
3 \\
3 \\
3\end{array}$ & $\begin{array}{l}4.0 \\
2.0 \\
2.0 \\
2.0\end{array}$ & $\begin{array}{l}.0200 \\
.0100 \\
.0100 \\
.0100\end{array}$ \\
\hline 29 & 39 & $F$ & $\begin{array}{r}6 \\
11\end{array}$ & $\mathrm{CC}$ & $\begin{array}{l}0 \\
1\end{array}$ & $\begin{array}{l}0 \\
0\end{array}$ & $\begin{array}{l}2 \\
2\end{array}$ & $\begin{array}{l}0 \\
1 .\end{array}$ & $\begin{array}{l}0 \\
0\end{array}$ & $\begin{array}{l}2 \\
2\end{array}$ & $\begin{array}{l}0.0 \\
1.0\end{array}$ & $\begin{array}{l}.0000 \\
.0050\end{array}$ \\
\hline 30 & 29 & F & $\begin{array}{r}7 \\
10\end{array}$ & $C C$ & $\begin{array}{l}0 \\
3\end{array}$ & $\begin{array}{l}0 \\
1\end{array}$ & $\begin{array}{l}2 \\
2\end{array}$ & $\begin{array}{l}1 \\
7\end{array}$ & $\begin{array}{l}0 \\
1\end{array}$ & $\begin{array}{l}2 \\
2\end{array}$ & $\begin{array}{l}1.0 \\
5.0\end{array}$ & $\begin{array}{l}.0050 \\
.0250\end{array}$ \\
\hline 31 & 39 & $F$ & $\begin{array}{r}? \\
10\end{array}$ & PJC & $\begin{array}{l}2 \\
3\end{array}$ & $\begin{array}{l}0 \\
0\end{array}$ & $\begin{array}{l}3 \\
3\end{array}$ & $\begin{array}{l}3 \\
6\end{array}$ & $\begin{array}{l}0 \\
0\end{array}$ & $\begin{array}{l}3 \\
3\end{array}$ & $\begin{array}{l}2.5 \\
4.5\end{array}$ & $\begin{array}{l}.0125 \\
.0225\end{array}$ \\
\hline 32 & 37 & M & $\begin{array}{l}8 \\
9\end{array}$ & CC & $\begin{array}{l}3 \\
8\end{array}$ & $\begin{array}{l}0 \\
1\end{array}$ & $\begin{array}{l}3 \\
3\end{array}$ & $\begin{array}{l}0 \\
3\end{array}$ & $\begin{array}{l}0 \\
1\end{array}$ & $\begin{array}{l}2 \\
3\end{array}$ & $\begin{array}{l}3.0 \\
5.5\end{array}$ & $\begin{array}{l}.0150 \\
.0275\end{array}$ \\
\hline
\end{tabular}


Table 2

Analysis of Variance Table

Variance

Source

$\begin{array}{cccc}\underline{\text { DF }} & \underline{\mathrm{SS}} & \underline{\mathrm{MS}} & \underline{\underline{F}} \\ 1 & 204.85 & 204.85 & 17.1 \\ \frac{62}{63} & 742.59 & 11.98 & \end{array}$

$\frac{V Q}{V E}=\frac{204.85}{11.98}=17.1$ 
Table 3

Mean Values of Gingival Index, Pocket Depth, and GCF Readings

\begin{tabular}{|c|c|c|c|c|c|c|c|c|}
\hline & \multicolumn{4}{|c|}{ Non-Restored } & \multicolumn{4}{|c|}{ Restored } \\
\hline & \multicolumn{2}{|c|}{ Mesial } & \multicolumn{2}{|c|}{ Distal } & \multicolumn{2}{|c|}{ Mesial } & \multicolumn{2}{|c|}{ Distal } \\
\hline & $\begin{array}{l}\text { Meter } \\
\text { Reading }\end{array}$ & $\mu l / \min$ & $\begin{array}{l}\text { Meter } \\
\text { Reading }\end{array}$ & $\mu \mathrm{l} / \mathrm{min}$. & $\begin{array}{l}\text { Meter } \\
\text { Reading }\end{array}$ & $\mu 1 / \mathrm{min}$. & $\begin{array}{l}\text { Meter } \\
\text { Reading }\end{array}$ & $\mu I / \min$. \\
\hline & 3.2 & .030 & 3.8 & .038 & 6.9 & .064 & 7.3 & .074 \\
\hline $\begin{array}{l}\text { Gingival } \\
\text { Index }\end{array}$ & \multicolumn{2}{|l|}{0.11} & \multicolumn{2}{|l|}{0.14} & \multicolumn{2}{|l|}{0.71} & \multicolumn{2}{|l|}{0.74} \\
\hline $\begin{array}{l}\text { Pocket } \\
\text { Depth }(\mathrm{mm})\end{array}$ & \multicolumn{2}{|l|}{2.4} & \multicolumn{2}{|l|}{2.5} & \multicolumn{2}{|l|}{2.6} & \multicolumn{2}{|l|}{2.7} \\
\hline
\end{tabular}


Table 4

Frequency Distribution of Restorations

\begin{tabular}{|c|c|c|c|c|c|c|c|c|c|c|c|c|}
\hline \multirow{2}{*}{$\begin{array}{c}\text { Tooth } \\
\#\end{array}$} & \multirow{2}{*}{$\begin{array}{l}\text { No of of } \\
\text { Teeth } \\
\text { Rest'd }\end{array}$} & \multirow{2}{*}{ 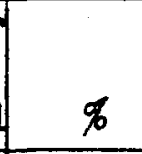 } & \multicolumn{10}{|c|}{ Type of Restorative Material } \\
\hline & & & $A^{*}$ & $\not 6$ & AFC & $\phi$ & $\mathrm{CC}$ & $\%$ & FGC & 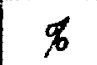 & PJC & $\%$ \\
\hline 4 & 5 & $14 \cdot 3$ & & & 3 & & 1 & & 1 & & & \\
\hline 5 & 6 & 17.1 & & & 5 & & 1 & & & & & \\
\hline 6 & 3 & 8.5 & & & & & 3 & & & & & \\
\hline 7 & 1 & 2.9 & & & 1 & & & & & & & \\
\hline 8 & 7 & 20.0 & 1 & & & & 3 & & & & 3 & \\
\hline 9 & 6 & 17.1 & & & & & 2 & & & & 4 & \\
\hline 10 & 4 & 11.4 & & & & & 3 & & & & 1 & \\
\hline 11 & 1 & 2.9 & & & & & 1 & & & & & \\
\hline 12 & 1 & 2.9 & & & 1 & & & & & & & \\
\hline 13 & 1 & 2.9 & & & & & 1 & & & & & \\
\hline Totals & 35 & 100.0 & 1 & 2.8 & 10 & 28.6 & 15 & 42.9 & 1 & 2.8 & 8 & 22.9 \\
\hline
\end{tabular}

* Abbreviations

$$
\begin{aligned}
A & =\text { Acrylic } \\
\text { AFC } & =\text { Acrylic Processed to Gold } \\
C C & =\text { Ceramo-Metal Crown } \\
\text { FGC } & =\text { Full Gold Crown } \\
\text { PJC } & =\text { Porcelain Jacket Crown }
\end{aligned}
$$


CHAPTER V

\section{DISCUSSION}

The dento-epithelial junction and ginglval sulcus area functions as a defense system for the synarthrosis articulation of tooth structure with alveolar process. Within this area a dynamic physiological balance is maintained to preserve the integrity of the periodontium and allow the stomatognathic system to function at its designed capacity.

Gingival inflammation represents the host's response to defend itself against micro-organisms and noxious stimuli entering the sulcus by diluting, removing or inactivating the foreign substance. Studies seem to suggest an inflammatory origin of crevicular fluid since its flow is known to increase with inflammation. Brill (1960) first suggested using crevicular fluid as a measure of gingival inflammation since it provided a quantitative means (as opposed to the subjectivity of clinical scoring) to monitor the physiology of the sulcular area.

Investigators have histologically observed inflammatory changes to some degree (such as alterations in microcirculation and PMN accumulation) in clinically normal marginal gingiva. The altered microcirculation is manifested as vasodilatation of the arterioles, metarterioles, and 
venules which eventually results in increased vascular permeability allowing fluid loss from the vascular compartment (Grant, Stern, and Everett-1972). This fluid enters the sulcus and will quantitatively reflect the degree of sulcular inflammation before clinical signs are evident (Loe and Holm-Pedersen-1965). Therefore, the advantage of monitoring the dgree of inflammation is the potentiality of preventing permanent tissue damage by not allowing the inflammatory process to progress to a chronic stage.

Some investigators contend there is no crevicular fluid flow in the clinically healthy marginal gingiva while others maintain there is. It is suggested that the presence or absence of crevicular fluid is a manifestation of the host response to noxious stimuli by the release and activation of endogeneous mediators of inflammation via immune mechanisms.

The identification of six known lysosomal enzymes (acid phophatase, $\beta$ glucuronidase, lysozyme, cathespsin $D$, protease, and aminopeptidase) in gingival crevicular fluid has suggested to some investigators a significant role of Iysosome enzymes in the pathogenesis of periodontitis. However, the possibility of their dual origin (bacterial or host cells) and the difficulty in obtaining substantial quantities for analysis has resulted in a limited number of 
investigations and few definitive conclusions (Cimasoni1974).

The statistically significant differences $(P<.001)$ between the crevicular fluid volumes obtained from restored and non-restored teeth indicates an inflammatory response associated with full coverage subgingival margins regardless of the type of restorative material used.

Limited visibility and accessibility to the oral cavity coupled with the advent of high speed rotary instrumentation taxes even the most highly skilled restorative clinician in minimizing trauma to the sulcular epithelium and dentogingival junction. The amount of gingival recession following restorative procedures is directly proportional to the amount of injury incurred by these structures. Another inherent weakness in the restorative procedures is the less than perfect adaptation that can be achieved between the margins of the restorative material and the tooth structure. It is known that this interface provides an uncleansible area for plaque accumulation which in turn is capable of activating the mechanism for the release of inflammatory mediators. Also, the cementing medium can serve as a noxious stimulu to the sulcular environment. Thus, forelgn materials (crowns and dental cements) are placed in close proximity to the non-keratinized sulcular epithelium with the potential to initiate an inflammatory response. 
The most frequently restored tooth in the sample studied was the maxillary right central incisor. This can be explained by the greater number of females (20) compared to males (15) surveyed. A greater percentage of teeth on the maxillary right had been restored (62.8\%) compared to the maxillary left (37.2). This observation may indicate a masticatory preference for the right side and the propensity for right-handedness in toothbrushing procedures.

The restorative material used most frequently was procelain-fused-to-gold $(42.9 \%)$ which is indicative of the arch position selected for this study (maxillary segment) and the preference for this type of restorative material since the development of more refined procelain to metal fusing techniques. Esthetics often is the main criteria utilized in the fabrication of procelain-fusedto-gold and acrylic-processed-to-gold which usually results in excessive contours in the gingival margin area. The local irritation caused by these excessive contours may be reflective of the significant difference of crevicular fluid volume between restored and non-restored teeth in this study since these two types of restorative materials account for approximately $70 \%$ of the restorations measured. The present investigation is in aggreement with the findings of Brill and Bjorn (1959) and Strauss et al. (1975) 
indicating an increase in gingival fluid volume associated 57 with extensive full coverage restorations and major connectors of removeable prosthesis (respectively).

The present findings correspond to those reported by Larato (1975) since the mean pocket depth for restored teeth was greater than for non-restored teeth.

Maruyama's (1976) observation of altered microcirculation associated with porcelain-fused-to-gold restorations is congruent with the significant difference in crevicular flow rate (see Table 3) noted in the present study $(42.9 \%$ of the restored teeth were porcelain-fused-to-gold).

Mahajan's (1976) histological evaluation of interdental papillary tissue adjacent to full coverage restorations corresponds to the present study indicating an inflammatory response associated with subgingival margins of crowns.

Suggestions for further investigations:

1. Standardization of gingival crevicular fluid meter values based on: (a) age, (b) sex, (c) tooth position in the arch, and (d) varying clinical degrees of inflammation.

2. A longitudinal study recording crevicular fluid volumes associated with extensive full coverage restorative cases prior to and during clinical procedures and at regular post insertion intervals.

3. Determine if there is a significant difference between types of restorative materials (including semi- and non-precious alloys) and crevicular flow. 
The crevicular fluid volume between restored and nonrestored teeth was compared on thirty-two adult patients between the ages of twelve and sixty. There was a significant difference $(P<.001)$ between the amount of crevicular fluid collected from restored teeth compared to non-restored teeth. Crevicular fluid was collected by means of standardized sterile filter paper strips and the volume determined using a gingival crevicular fluid meter.

The fragility and dynamic nature of the dento-gingival function and sulcus area was discussed in relation to gingival inflammation, full coverage restorative procedures, and the presence of gingival crevicular fluid. The chemical constituents of gingival crevicular fluid and their possible implications as factors in periodontal pathology were presented. The necessity for further studies associated with gingival crevicular fluid were mentioned.

The following conclusions can be made in view of the results obtained during this study:

1. Subclinical inflammatory changes associated with subgingival full coverage restorations can be objectively and quantitatively measured using 
standardized techniques and a gingival crevicular fluid meter.

2. Subgingival placement of full coverage margins should be aroided whenever possible.

3. Full coverage restorative procedures necessitate:

a. Proper diagnosis.

b. Proper tooth preparation.

c. Utilization of dental materials to gain full advantage of their favorable properties.

d. Preparation, retraction, impression, and temporization techniques should be utilized which cause the least possible disruption to the integrity of the marginal gingiva and the dento-gingival junction.

e. Final crown contours should reproduce natural tooth contours and should not alter the health of the periodontium.

4. Patients with subgingival full coverage restorations should be instructed in proper oral hygiene procedures and placed on a definite recall schedule involving prophylaxsis and re-evaluation of gingival conditions. 


\section{BIBLIOGRAPHY}

Amsterdam, M., and Fox, L. "Provisional SplintingPrinciples and Techniques." Dent. Clin. No. Am., (1959), 73-99.

Alfano, Michael C. "The Origin of Gingival Fluid." J. Theor. Biol., Vol. 47, (1974), 127-136.

Berman, Martin H. "The Complete-Coverage Restoration and the Gingival Sulcus." J. Prosth. Dent., Vol. 29, No. 3, (March, 1.973), 301-309.

Black, G.V. "The Periosteum and Peridental MembraneInterfibrous Elements of the Peridental Membrane." The Dent. Review, Vol. I, No. 6, (April 15, 1887), 289-302.

Black, G.V. "The Fibers and Glands of the Peridental Membrane." The Dent. Cosmos, Vol. XLI, No. 2, (Feb., 1899), 101-122.

Black, G.V. Special Dental Pathology. 2nd ed. Chicago: Medico-Dental Publishing Co., 1920.

Bödecker, Charles F., and Cahn, Lester R. "The Histology and Function of the Gingiva." Dent. Items of Interest, Vol. 53, (Feb., 1931), 94.

Bödecker, Charles F. "Dental Erosion: Its Possible Causes and Treatment." The Dent. Cosmos, Vol. IXXV, (Nov., 1933), 1056-1062.

Borden, S.M.; Golub, L.M.; and Kleinberg, I. "An Intracrevicular Technique for Monitoring Gingival Crevicular Flu1d (GCF) Flow." J. Dent. Res., Vol. 53, (Feb., 1974), Abstract \# 48\%, 175 .

Erandtzaeg, Per, and Mann, wallace V., Jr. "A Comparative Study of the Iysozyme Activity of Human Gingival Pocket Fluid, Serum, and Saliva." Acta Odont. Scand., Vol. 22, (1964), 441-455.

Brill, Niels, and Björn, Hilding. "Passage of Tissue Fluid into Human Gingival Pockets." Acta Odont. Scandinav., Vol. 17, (1959), 11-21. 
Brill, Niels, and Krasse, Bo. "Effect of Mechanical Stimulation on Flow of Tissue Fluid Through Gingival Pocket Epithelium." Acta Odont. Scandinav., Vol. 17, (1959), 115-130.

Brill, Niels. "Influence of Capillary Permeability on Flow of Tissue Fluid into Gingival Pockets." Acta odont. Scandinav., Vol. 17, (1959a), 23-33.

Brill, Niels. "Effect of Chewing on Flow of Tissue Fluid into Human Gingival Pockets." Acta Odont. Scandinav., Vol. $17,(1959 \mathrm{~b}), 277-281$.

Brill, Niels. "Removal of Particles and Bacteria from Gingival Pockets by Tissue Fluid." Acta Odont. Scandinav., Vol. 17, (1959c), 431-440.

Brill, Niels, and Brönnestam, Rolf. "Immuno-Electrophoretic Study of Tissue Fluid from Gingival Pockets." Acta Odont. Scandinav., Vol. 18, (1960), 95-100.

Brill, Niels. "The Gingival Pocket Fluid." Acta Odont. Scandinav., Vol. 20, Suppl. 32, (1962).

Burch, James G. "Periodontal Considerations in Operative Dentistry." J. Prosth. Dent., Vol. 34, No. 2, (Aug., 1975), 156-163.

Carraro, J.J.; Milstein, S.; Sznajder, N.; and Zdrojewski, D. "Electroforesis en Agar Del Fluid Gingival de Encias Normales." Rev. A. Odont. Argentina, Vol. 52, (March, 1964), 77-80.

Cimasoni, G. Monographs in Oral Science Vol. 3 - The Crevicular Fluid. Switzerland: S. Karger AG, 1974.

Egelberg, Jan. "Cellular Elements in Gingival Pocket Fluid." Acta Odont. Scandinav., Vol. 21, (1963a), 280-287.

Egelberg, Jan. "Diffusion of Histamine into the Gingival Crevice and Through the Crevicular Epithelium." Acta odont. Scandinav., Vol. 21, (1963b), 271-282.

Egelberg, Jan. "Gingival Exudate Measurements for Evaluation of Inflammatory Changes of the Gingivae." odont. Revy, Vol. 15, (1964), 381-398.

Egelberg, Jan, and Attström, Rolf. "Comparison Between Orfice and Intracrevicular Methods of Sampling Gingival Fluid." J. Periodont. Res., Vol. 8, No. 6, (1973), 384-388. 
Gavin, J.B., and Collins, A.A. "The Occurrence of Bacteria Within the Clinicaliy Healthy Gingival Crevice." J. Periodont., Vol. 32, (1961a), 198-201.

Gavin, J. B., and Collins, A.A. "An Evaluation of the Antimicrobial Effect of the Fluid Exudate from the Clinically Healthy Gingival Crevice." J. Periodont., Vol. 32, (1961b), 99-101.

Glickman, Irving. Clinical Periodontology. Philadelphia: W.B. Saunders Co., 1972 .

Goldman, Henry M., and Cohen, Walter D. Periodontal Therapy. St. Louis: The C.V. Mosby Co., 1973.

Golub, L.M.; Borden, S.M.; and Kleinberg, I. "Urea Content of Gingival Crevicular Fluid and Its Relation to Periodontal Disease in Humans." J. Periodont. Res., Vol. 6, (1971), 243-251.

Golub, L.M.; Stakiw, J.E.; and Singer, D.L. "Collagenolytic Activity of Human Gingival Crevice Fluid." J. Dent. Res., Vol. 53, No. 6, (Nov.-Dec., 1974), 1501 .

Golub, Lorne M., and Kleinberg, Israel. "Gingival Crevicular Fluid: A New Diagnostic Aid in Managing the Periodontal patient." Oral Sciences Reviews, 1976. (To be published.)

Grant, Daniel A.; Stern, Irving B.; and Everett, Frank G. Orban's Periodontics. St. Louis: The C.V. Mosby Co., 1972 .

Gustafsson, Gunnar T., and Nilsson, Inga Marie. "Fibrinolytic Activity in Fluid from Gingival Crevice." Soc. Exper. Biol. and Med. Proc., Vol. 1.06, (1961), 2777-280.

Harvey, Paul M. "Elimination of Extraneous Material from the Gingival Crevice." J. Periodont., Vol. 33, (1962), 231-237.

Holm-Pedersen, Poul; Agerbaek, Nina; and Theilade, Else. "Experimental Gingivitis in Young andElderly Individuals." J. Clinical Periodont., Vol. 2, (1975), 14-24.

Kleinberg, I., and Hall G. "PH and Depth of Gingival Crevices in Different Areas of the Mouths of Fasting Humans." J. Periodont. Res., Vol. 3, (1968), 109-117.

Krasse, Bo, and Egelberg, Jan. "The Relative Proportions of Sodium, Potassium and Calcium in Gingival Pocket Fluid." Acta Odont. Scandinav.,. Vol. 20, (1962), 143-152. 
Kronfeld, Rudolf. Histopathology of the Teeth and Their Surrounding structures. Philadelphia: Lea and Febiger, 1933.

Kronfeld, Rudolf. Histopathology of the Teeth and Their Surrounding structures. 3rd ed. Philadelphia: Lea and Febiger, 1949 .

Larato, Dominick C. "Effects of Artificial Crown Margin Extension and Tooth Brushing Frequency on Gingival Pocket Depth." J. Prosth. Dent., Vol. 34, No. 6, (Dec., 1975), 640-643.

Lie, Tryggve, and Selvig, Knut A. "Formation of an Experimental Dental Cuticel." Scand. J. Dent. Res., Vol. 83, (1975), 145-152.

Löe, Harald. "Physiological Aspects of the Gingival Pocket." Acta Odont. Scandinav., Vol. 19, (1961), 387-395.

Löe, Harald. "Reactions of Marginal Periodontal Tissues to Restorative Procedures." Internat. Dent. J., Vol. 18, No. 41, (Sept., 1962), 759-778.

Löe, Harald, and Holm-Pedersen Poul. "Absence and Presence of Fluid from Normal and Inflamed Gingivae." Periodontics, Vol. 3, No. 4, (July/Aug., 1965), 171-177.

Löe, Harald. "The Gingival Index, The Plaque Index, and The Retention Index Systems." J. Periodont., Vol. 38, (1967), 61.

Mc'Call, John Oppie. "Studies in the Et1ology of Approximal and Gingival Caries." J. Dent. Res., Vol. 6, (Dec., $1924), 461$.

Mahajan, Meera. "Histological Evaluation of Gingiva in Complete Crown Restorations." Unpublished M.S. Thesis, Loyola University Dental School of Chicago, 1976.

Makinen, K.K., and Hyyppä, T. "A Biochemical Study of the Origin of Arginine Aminopeptidases in Human Gingival Fluid." Arch. Oral Biol., Vol. 20, (1975), 509-514.

Mann, wallace V., Jr. "The Correlation of Gingivitis Pocket Depth and Exudate from the Gingival Crevice." J. Perlodont., Vol. 34, (1963), 379-387.

Marcum, James $S$. "The Effect of Crown Marginal Depth Upon Gingival Tissue." J. Prosth. Dent., Vol. 17, No. 5, (May, 1967), 479-487. 
Maruyama, Takao; Simoosa, Takaji; and Ojima, Hiroo.

"Morphology of Gingival Capillaries Adjacent to Complete Crowns." J. Prosth. Dent., Vol. 35, No. 2, (Feb., 1976), $179-184$.

Miller, Samuel Charles. Textbook of Periodontia (Oral Medicine). York, Pa.: The Maple Press Co., 1938.

Mörmann, W.; Regolat1, B.; and Renggli, H.H. "Gingival Reaction to Well-Fitted Subgingival Proximal Gold Inlays." J. Clinical Periodont., Vol. 1, (1974), 120-125.

Morris, Melvin I. "Artificial Crown Contours and Gingival Health." J. Prosth. Dent., Vol. 12, No. 6, (1962), 1146-1156.

Mount, G.J. "Crowns and the Gingival Tissues." Austral. Dent. J., Vol. 15, No. 4, (Aug., 1970), 253-258.

Nemetz, Harold. "Tissue Management in Fixed Prosthodontics." J. Prosth. Dent., Vol. 31, No. 6, (June, $1974), 628-636$.

Newcomb, G.M. "The Relationship Between the Location of Subgingival Crown Margins and Gingival Inflammation." J. Periodont., Vol. 45, (1974), 151-154.

Oliver, R.C.; Holm-Pedersen, P.; and Löe, H. "The Correlation Between Clinical Scoring, Exudate Measurements and Microscopic Evaluation of Inflammation in the Gingiva." J. Periodont. Res., Vol. 40, (1969), 201-209.

Orban, J.E., and Stallard, R.E. "Gingival Crevicular Fluid: A Reliable Predictor of Gingival Health?" J. Periodont., Vol. 40, (1969), 231-235.

Ramf jord, S.P.; Berry, H.M.; Charbeneau, G.T.; Lee, R.E.; Pavone, B.W.; and Phililps, R.W. "Report of the Committee on Scientific Investigation of the American Academy of Restorative Dentistry." J. Prosth. Dent., Vol. 32, No. 2, (Aug., 1974), 198-221.

Renggli, H.H., and Regolati, B. "Intracrevicular Sampling of Leukocytes Using Plastic Strips." Helvet. Odont. Acta, Vol. 16, (Oct., 1972), 93-99.

Sandalli, Peker, and wade, A. Bryan. "Alterations in Crevicular Fluid Flow During Healing Following Gingivectomy and Flap Procedures." J. Periodont. Res., Vol. 4, (1969), 314-318. 
Serres, Antoine. "Essai sur I Anatomie et la Physiologie des Dents, ou Nouvelle Theorie de la Dentition."

Paris: Mequignon, Marvis, 1817.

Shern, R.J.; Von Mohr, G.; and Joly, 0 . "Crevicular Fluid Flow and Cytopathology as objective Clinical Measurements." J. Dent. Res., Vol. 53, (Feb., 1974), 175.

Sicher, Harry. Orban's Oral Histology and Embryology. St. Louis: The C.V. Mosby Co., 1966.

Squier, C.A., and Johnson, N.W. "Permeability of Oral Mucosa." Brit. Med. Bull., Vol. 31, No. 2, (1975), 169-175.

Stallard, Rs.chard E. "Periodontal Microcirculation and the Gingival Crevicular Fluid." Parodontologie and Academy Rev., Vol. 1, No. 1, (Mar., 1967), 34-45.

Stillman, Paul R., and Mc'Call, John Oppie. A Textbook of Clinical Periodontia. New York: Macmilian Co., 1927 .

Strauss, S.; Goldberg, A.; and Zarb, B.A. "Subclinical Inflammatory Changes Under Mandibular Partial Dentures." J. Dent. Res., Vol. 54, Special Issue A, (1975) Abstract \#173, 88 .

Sueda, T.; Cimasoni, G.; and Held, A.J. "Histochemical Study of Human Gingival Fluid." Parodontologie, Vol. 20, No. 4, (Dec., 1966), 141-146.

Suppipat, Nophadol, "The Use of the HAR-600 Ginglval Crevice Fluid Meter in Clinical Research." Unpublished M.S. Thesis, University of Oslo, 1976.

Toto, Patrick D., and Sicher, Harry. "The Epithelial Attachment." Periodontics, Vol. 2, No. 4, (July/Aug., $1964), 154-156$.

Trivedi, S.C., and Talim, S.T. "The Besponse of Human Gingiva to Restorative Materials." J. Prosth. Dent., Vol. 29, No. 1, (Jan., 1973), 73-79.

Turner, Harold; Ruben, Morris P.; Frankl, Spencer N.; Sheff, Michael; and Silberstein, Stevan. "Visualization of the Microcirculation of the Periodontium." J. Periodont. Res., Vol. 40, (1969), 222-230. 
Volchansky, A.; Cleaton-Jones, P.; and Retief, D.H. "Study of Surface Characteristics of Natural Teeth and Restorations Adjacent to Gingiva." J. Prosth. Dent., Vol. 31, No. 4, (April, 1974), 411-421.

Waerhaug, J., and Stee, E. "The Presence or Absence of Bacteria in Gingival Pockets and the Reaction in Healthy Pockets to Certain Pure Cultures." Odont. Tskr., Vol. $60,(1952), 1-24$.

Waerhaug, J. "The Gingival Pocket: Anatomy, Pathology, Deepening and Elimination." Odont. Tskr., Vol. 60, Suppl. 1, (1952).

Waerhaug, J. "The Source of Mineral Salts in Subgingival Calculus." J. Dent. Res., Vol. 34, (1955), 563-568. Waerhaug, J. "Histologic Considerations Which Govern Where the Margins of Restorations Should Be Located in Relation to the Gingiva." Dent. Clin. No. Am., Symposium on Practical Periodontal Therapy, TMarch, $1960), 161-176$.

Waerhaug, J. "Periodontology and Partial Prosthesis." Internat. Dent. J., Vol. 18, No. 1, (March, 1968), 101-105.

Weinstein, Ephraim, and Mandel, Irwin D. The Fluid of the Gingival Sulcus." Pexiodontics, Vol. 2, No. 4, (July/ Aug., 1.964), 147-153.

Weinstein, Ephraim; Mandel, Irwin D.; Salkin, Albert; Oshrain, Herbert I.; and Pappas, George D. "Studies of Gingival Fluid." Periodontics, Vol. 5, No. 4, (July/Aug., 1967), 161-166.

Zájiček, $0 .$, and Kindlová, M. "Oxygen Consumption in Different Degrees of Gingivitis." J. Periodont. Res., Vol. 7, (1972), 242-246. 
APPENDIX 


\author{
LOYOLA DENTAL SCHOOL \\ FIXED PROSTHODONTICS DEPARTMENT \\ CREVICULAR FLUID VOLUME MEASUREMENTS
}

\section{PATIENT CONSENT FORM}

The purpose of this study is to determine if there is an increase in the amount of fluid flowing from the space between the teeth and gums after placing a crown (cap).

This preliminary study will utilize an instrument that measures very small amounts of fluid and possibly can be used to detect gum disease before it has progressed to an advanced stage.

The procedure will involve drying each tooth with cotton rolls, then placing a small sterile piece of filter paper next to the tooth near the gums for about 3 seconds. Several teeth will be measured in this manner. This will not produce any discomfort or have any 111 effect whatsoever on the gums or the teeth. The entire procedure including filling out the questionnaire should take approximately 20 minutes.

If at any time during the procedure you want to witharaw your participation in this study, you are free to do so.

I HAVE READ THE ABOVE INFORMATION AND WILI PARTICIPATE IN THIS STUDY. PARTICIPANT'S SIGNATURE

DATE 
Patient Date

Time

Address

City

State

Zip

Phone \#

Age

Birth Date

\begin{tabular}{|c|c|c|c|c|c|c|c|c|c|c|c|}
\hline$\underset{\#}{\text { Tooth }}$ & $N-\operatorname{Res}^{\prime} d$ & $\frac{\operatorname{Res}^{\prime} d}{\text { Age }}$ & $\begin{array}{l}\text { Res. } \\
\text { Mat. }\end{array}$ & $\begin{array}{l}\text { M-Fluid } \\
\text { Volume }\end{array}$ & $\begin{array}{l}\text { Ging' I }^{\prime} \\
\text { Index }\end{array}$ & $\begin{array}{l}\text { Poc't } \\
\text { Depth } \\
\text { (mm) }\end{array}$ & $\begin{array}{l}\text { D-Fluid } \\
\text { Volume }\end{array}$ & $\begin{array}{l}\text { Ging' I } \\
\text { Index* }\end{array}$ & $\begin{array}{l}\text { Poc't } \\
\text { Depth } \\
\text { (mm) }\end{array}$ & $\begin{array}{l}\text { Fluid } \\
\text { Vol. Ave }\end{array}$ & $\mu l$ \\
\hline 4 & & & & & & & & & & & \\
\hline 5 & & & .. & & & & & & & & \\
\hline 6 & & & & & & & & & & & \\
\hline 7 & & & & & & & & & & & \\
\hline 8 & & & & & & & & & & & \\
\hline 9 & & & & & & & & & & & \\
\hline 10 & & & & & & & & & & & \\
\hline 11 & & & & & & & & & & & \\
\hline 12 & & & & & & & & & & & \\
\hline 13 & & & & & & & & & & & \\
\hline
\end{tabular}

*Gingival Index (after Loe \&

Silness; J.Perio.,1967)

$0=$ Normal gingiva.

1 = Mild Inflammation: Slight change in color, slight edema, no bleeding on probing.

2 = Moderate Inflammation: Redness, edema, and glazing; bleeding on probing.

3 = Severe Inflammation: Marked redness and edema; ulceration; tendency to spontaneous bleeding.
Abbreviations:

1. N-Res'd = Non-restored margin

2. Res'd = Restored margin (crown)

3. Res.Mat. = Restorative material:

a. $A=$ Acrylic crown

b. $A F C=A c r y l i c-p r o c e s s e d-$ to-gold

c. $\quad C C=$ Ceramo-metal crown

d. $F G C=$ Full gold crown

e. $\quad \mathrm{PJC}=$ Porcelain jacket crown

4. Poc't = Pocket depth in millimeters 
APPROVAL SHEET

The thesis submitted by Lee Merle Jameson has been approved by the following Committee:

Dr. William F. Malone

Professor, Fixed Prosthodontics, Loyola

Dr. Robert J. Pollack Jr.

Associate Professor and Chairman, Histology, Loyola

Dr. Patrick D. Toto

Professor and Chairman, Oral Pathology, Loyola

The final copies have been examined by the director of the thesis and the signature which appears below verifies the fact that any necessary changes have been incorporated and that the thesis is now given final approval by the Committee with reference to content and form.

The thesis is therefore accepted in partial fulfillment of the requirements for the degree of Master of Science.

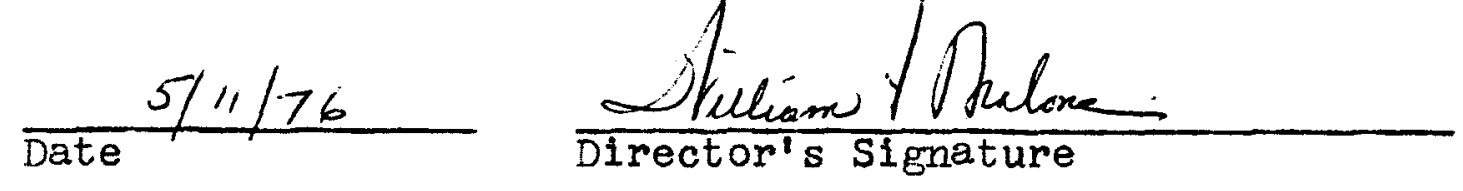

